Marquette University

e-Publications@Marquette

$10-2012$

\title{
Structural, Spectroscopic, and Electrochemical Properties of Nonheme Fe(II)-Hydroquinonate Complexes: Synthetic Models of Hydroquinone Dioxygenases
}

\author{
Amanda E. Baum \\ Marquette University, amanda.baum@marquette.edu \\ Heaweon Park \\ Marquette University \\ Denan Wang \\ Marquette University, denan.wang@marquette.edu \\ Sergey Lindeman \\ Marquette University, sergey.lindeman@marquette.edu \\ Adam T. Fiedler \\ Marquette University, adam.fiedler@marquette.edu
}

Follow this and additional works at: https://epublications.marquette.edu/chem_fac

Part of the Chemistry Commons

\section{Recommended Citation}

Baum, Amanda E.; Park, Heaweon; Wang, Denan; Lindeman, Sergey; and Fiedler, Adam T., "Structural, Spectroscopic, and Electrochemical Properties of Nonheme Fe(II)-Hydroquinonate Complexes: Synthetic Models of Hydroquinone Dioxygenases" (2012). Chemistry Faculty Research and Publications. 377.

https://epublications.marquette.edu/chem_fac/377 


\title{
Structural, Spectroscopic, and Electrochemical Properties of Nonheme Fe(II)-Hydroquinonate Complexes: Synthetic Models of Hydroquinone Dioxygenases
}

\author{
Amanda E. Baum \\ Department of Chemistry, Marquette University \\ Milwaukee, WI \\ Heaweon Park \\ Department of Chemistry, Marquette University \\ Milwaukee, WI \\ Denan Wang \\ Affiliation Department, Affiliation University \\ Affiliation City \\ Sergey V. Lindeman \\ Department of Chemistry, Marquette University \\ Milwaukee, WI \\ Adam T. Fiedler \\ Department of Chemistry, Marquette University \\ Milwaukee, WI
}

Dalton Transactions, Vol. 41, No. 39 (October 2012): pg. 12244-12253. DOI. This article is @ Royal Society of Chemistry and permission has been granted for this version to appear in e-Publications@Marquette. Royal Society of Chemistry does not grant permission for this article to be further copied/distributed or hosted elsewhere without the express permission from Royal Society of Chemistry. 
NOT THE PUBLISHED VERSION; this is the author's final, peer-reviewed manuscript. The published version may be accessed by following the link in the citation at the bottom of the page.

\section{Abstract:}

Using the tris(3,5-diphenylpyrazol-1-yl)borate ( $\left.{ }^{\mathrm{Ph} 2} \mathrm{Tp}\right)$ supporting ligand, a series of mono- and dinuclear ferrous complexes containing hydroquinonate (HQate) ligands have been prepared and structurally characterized with X-ray crystallography. The monoiron(II) complexes serve as faithful mimics of the substrate-bound form of hydroquinone dioxygenases (HQDOs) - a family of nonheme Fe enzymes that catalyze the oxidative cleavage of 1,4-dihydroxybenzene units. Reflecting the variety of HQDO substrates, the synthetic complexes feature both mono- and bidentate HQate ligands. The bidentate HQates cleanly provide five-coordinate, high-spin $\mathrm{Fe}$ (II) complexes with the general formula $\left[\mathrm{Fe}\left({ }^{\mathrm{Ph} 2} \mathrm{Tp}\right)\left(\mathrm{HL}^{\mathrm{X}}\right)\right](\mathbf{1 X})$, where $\mathrm{HL}^{\mathrm{X}}$ is a HQate(1-) ligand substituted at the 2-position with a benzimidazolyl (1A), acetyl (1B and 1C), or methoxy (1D) group. In contrast, the monodentate ligand 2,6-dimethylhydroquinone $\left(\mathrm{H}_{2} \mathrm{~L}^{\mathrm{F}}\right)$ exhibited a greater tendency to bridge between two $\mathrm{Fe}(\mathrm{II})$ centers, resulting in formation of $\left[\mathrm{Fe}_{2}\left({ }^{\mathrm{Ph} 2} \mathrm{Tp}\right)_{2}(\mu-\right.$ $\left.\left.L^{F}\right)(\mathrm{MeCN})\right][\mathbf{2 F}(\mathbf{M e C N})]$. However, addition of one equivalent of "free" pyrazole $\left({ }^{\mathrm{Ph} 2} \mathrm{pz}\right)$ ligand provided the mononuclear complex, $\left[\mathrm{Fe}\left({ }^{\mathrm{Ph} 2} \mathrm{Tp}\right)\left(\mathrm{HL}^{\mathrm{F}}\right)\left({ }^{\mathrm{Ph} 2} \mathrm{pz}\right)\right]\left[\mathbf{1} \mathbf{F}\left({ }^{\mathrm{Ph} 2} \mathrm{pz}\right)\right]$, which is stabilized by an intramolecular hydrogen bond between the $\mathrm{HL}^{\mathrm{F}}$ and ${ }^{\mathrm{Ph} 2} \mathrm{pz}$ donors. Complex $\mathbf{1 F}\left({ }^{\mathrm{Ph} 2} \mathrm{pz}\right)$ represents the first crystallographically-characterized example of a monoiron complex bound to an untethered HQate ligand. The geometric and electronic structures of the Fe/HQate complexes were further probed with spectroscopic (UV-vis absorption, ${ }^{1} \mathrm{H}$ NMR) and electrochemical methods. Cyclic voltammograms of complexes in the $\mathbf{1 X}$ series revealed an Fe-based oxidation between 0 and $-300 \mathrm{mV}\left(\mathrm{vs} . ~ \mathrm{Fc}^{+/ 0}\right)$, in addition to irreversible oxidation(s) of the HQate ligand at higher potentials. The one-electron oxidized species ( $\mathbf{1 X}_{\mathbf{o x}}$ ) were examined with UV-vis absorption and electron paramagnetic resonance (EPR) spectroscopies.

\section{Introduction}

The degradation of single- and multi-ring aromatic hydrocarbons by bacteria is a key component of the global carbon cycle and the basis of bioremediation technologies. In aerobic environments, the catabolism of aromatic compounds is dependent on nonheme iron dioxygenases that cleave aromatic rings with incorporation of both atoms of $\mathrm{O}_{2}$ into the product. ${ }^{1}$ Such transformations are challenging due to the intrinsic stability of aromatic systems and the high activation barrier to reaction with triplet dioxygen. With the notable exception of the intradiol catechol dioxygenases, the active sites of ring-cleaving dioxygenases overcome these obstacles by coordinating

Dalton Transactions, Vol. 41, No. 39 (October 2012): pg. 12244-12253. DOI. This article is @ Royal Society of Chemistry and permission has been granted for this version to appear in e-Publications@Marquette. Royal Society of Chemistry does not grant permission for this article to be further copied/distributed or hosted elsewhere without the express permission from Royal Society of Chemistry. 
both substrate and $\mathrm{O}_{2}$ to a single $\mathrm{Fe}$ (II) site. ${ }^{2}$ The iron center is typically attached to the protein by a facial array of one carboxylate (Asp or Glu) and two His residues (Scheme 1), ${ }^{3}$ although variants of this 2-His-1-carboxylate motif have recently been reported. ${ }^{4}$<smiles></smiles><smiles>O=C(O[Na])O[Na]</smiles>

hydroquinone I<smiles>O=C(O)c1cc(O)ccc1O</smiles>

gentisate<smiles>O=C(O)Cc1cc(O)ccc1O</smiles>

homogentisate<smiles>Oc1ccc(O)c(Cl)c1</smiles>

chlorohydroquinone<smiles>Oc1cc(Cl)c(O)c(Cl)c1</smiles>

2,6-dichlorohydroquinone

\section{Scheme 1}

While the well-studied extradiol catechol dioxygenases (ECDOs) are the prototypical ring-cleaving dioxygenases, ${ }^{2,5}$ members of this enzymatic family employ a remarkable variety of substrates, including protocatechuates, ${ }^{6}$ 2-aminophenols, ${ }^{7}$ and salicylates. ${ }^{8}$ Of particular relevance to this manuscript are dioxygenases that cleave hydroquinones (HQs = 1,4-dihydroxybenzene and its derivatives). The HQ-cleaving dioxygenases (HQDOs) can be grouped into two categories. The first class oxidizes substrates with carboxylate groups at the 2-position of the aromatic ring, namely, gentisate ${ }^{9}$ and homogentisate ${ }^{10}$ (2,5-dihydroxybenzoate and 2,5dihydroxyphenylacetate, respectively; Scheme 1). In these enzymes, the substrate likely binds to iron in a bidentate manner via the 
phenolate and carboxylate donors. ${ }^{11}$ In the second class, the substrate coordinates in a monodentate fashion, since the halogenated or unsubstituted HQs lack a metal-binding moiety at the ortho position. Examples include 2,6-dichlorohydroquinone 1,2-dioxygenase (PcpA), ${ }^{12}$ chlorohydroquinone dioxygenase (LinE), ${ }^{13}$ and hydroquinone 1,2dioxygenase $(\mathrm{MnpC}) \cdot{ }^{14}$

While there have been few mechanistic studies of the hydroquinone 1,2-dioxygenases, the proposed catalytic cycles largely follow the pattern derived from extensive studies of the ECDOs. ${ }^{12 a}$ Coordination of the deprotonated HQ substrate to the $\mathrm{Fe}$ (II) center displaces some or all of the $\mathrm{H}_{2} \mathrm{O}$ ligands found in the resting state (Scheme 1), thereby facilitating $\mathrm{O}_{2}$ binding to the iron center.

Formation of a short-lived ferric-superoxo intermediate is thought to trigger the transfer of one electron from the substrate ligand to iron, resulting in a bound $p$-benzosemiquinone radical. The existence of this putative intermediate would likely require deprotonation of the distal $\mathrm{OH}$ group by a second-sphere residue, although it is not clear whether these three events $\left(\mathrm{O}_{2}\right.$ coordination, electron transfer, and proton transfer) occur in a stepwise or concerted manner. The degree of semiquinone character on the substrate ligand in the $\mathrm{O}_{2}$-bound form of the enzyme is also uncertain; for instance, a recent computational study by $\mathrm{Ye}$ and $\mathrm{Neese}^{15}$ has cast doubt on the existence of a superoxo-Fe(II)-semiquinone intermediate in the ECDO (and, by extension, the HQDO) mechanism. While the nature of this intermediate remains disputed, it is well-established that the next step of the catalytic cycle involves generation of an Fe(II)-alkylperoxo species, which undergoes a Criegee rearrangement and hydrolysis to eventually yield the ring-opened product. ${ }^{15-16}$

Unanswered questions regarding the HQDOs can be answered, in part, through the development of synthetic complexes that replicate the structure and/or function of the enzyme active site. Remarkably, a survey of the literature found only a single example of a crystallographically-characterized monoiron(II)-hydroquinonate complex: $\mathrm{Fe}(\mathrm{L})_{2}$, where is $\mathrm{L}$ is a deprotonated Schiff base of 2,5dihydroxybenzaldehyde. ${ }^{17}$ The dearth of reported Fe/HQ complexes is partly due to the ability of hydroquinonate (HQate) ligands to adopt a bridging position between metal centers, as demonstrated by structures of diiron(III)-porphyrin and -salen complexes with bridging and permission has been granted for this version to appear in e-Publications@Marquette. Royal Society of Chemistry does not grant permission for this article to be further copied/distributed or hosted elsewhere without the express permission from Royal Society of Chemistry. 
HQate dianions. ${ }^{18,19}$ Recently, Machonkin and Holland described the formation and ${ }^{1} \mathrm{H}$ NMR characterization of a mononuclear iron(II)-2methylhydroquinonate complex supported by the $1,3,5-$ tris(tolylideneimino)cyclohexane ligand; ${ }^{20}$ however, this species is unstable and it was not possible to obtain crystals suitable for crystallographic analysis.

In this manuscript, we report the synthesis and X-ray structural characterization of several monoiron(II) complexes containing HQate ligands. Each complex features the tris(3,5-diphenylpyrazol-1$\mathrm{yl}$ )borate(1-) supporting ligand ( $\left.{ }^{\mathrm{Ph} 2} \mathrm{Tp}\right)$, as substituted Tp ligands are well-known to faithfully mimic the coordination environment of the 2His-1-carboxylate facial triad. ${ }^{21}$ We found that inclusion of bulky phenyl groups at the 3-positions of the pyrazole rings generally discourages formation of the diiron(II) $\mu$-hydroquinonate(2-) complexes, although dinuclear species were generated with certain HQs. As shown in Scheme 2, two types of HQ ligands were employed in this study: i) bidentate (or "tethered") ligands that feature an ortho substituent capable of metal coordination $\left(\mathrm{H}_{2} \mathrm{~L}^{\mathrm{A}-\mathrm{E}}\right.$ ), and (ii) the monodentate (or "untethered") ligand 2,6-dimethylhydroquinone $\left(\mathrm{H}_{2} \mathrm{~L}^{\mathrm{F}}\right)$. These HQs were selected because they reflect the range of substrates oxidized by HQDOs, with the monodentate and bidentate ligands resembling (chloro)hydroquinones and (homo)gentisates, respectively. \{NOTE: The series also includes 2-hydroxyacetophenone $\left(\mathrm{H}_{2} \mathrm{~L}^{\mathrm{C}}\right)$ as a control to properly evaluate the role of the distal $-\mathrm{OH}$ group in tuning the structural and electronic properties of our HQDO models. Each of the resulting complexes was characterized with crystallographic, spectroscopic (UV-vis absorption, ${ }^{1} \mathrm{H}$ NMR), and electrochemical techniques. Indeed, we report here the first $X$-ray structure of a mononuclear Fe complex featuring an untethered hydroquinonate ligand. We also employed spectroscopic methods, including electron paramagnetic resonance (EPR), to examine the ferric species generated upon one-electron oxidation of the monoiron(II) complexes. These results lay the foundation for future studies that will explore the $\mathrm{O}_{2}$ reactivity of complexes that mimic the enzyme-substrate intermediates of HQDOs.

Dalton Transactions, Vol. 41, No. 39 (October 2012): pg. 12244-12253. DOI. This article is @ Royal Society of Chemistry and permission has been granted for this version to appear in e-Publications@Marquette. Royal Society of Chemistry does not grant permission for this article to be further copied/distributed or hosted elsewhere without the express permission from Royal Society of Chemistry. 


$$
2 \mathbf{X}=\left[\mathrm{Fe}_{2}\left({ }^{\mathrm{Ph} 2} \mathrm{Tp}\right)_{2}\left(\mu-\mathrm{L}^{\mathrm{X}}\right)\right]
$$

\section{Scheme 2}

\section{Results and Discussion}

\section{Fe(II) Complexes with Tethered Hydroquinonate Ligands - Synthesis and Solid State Structures}

The mononuclear iron(II) complexes 1A-D (Scheme 2) were prepared by mixing equimolar amounts of $\mathrm{K}\left({ }^{\mathrm{Ph} 2} \mathrm{Tp}\right)$ and $\mathrm{FeX}_{2}(\mathrm{X}=\mathrm{Cl}$ or OTf) with the singly-deprotonated ligands, ${ }^{-} \mathrm{HL}^{\mathrm{A}-\mathrm{D}}$, in $\mathrm{MeCN}$ (or $\mathrm{MeCN} / \mathrm{CH}_{2} \mathrm{Cl}_{2}$ solvent mixture). The resulting air-sensitive complexes dissolve easily in $\mathrm{CH}_{2} \mathrm{Cl}_{2}$, but are largely insoluble in more polar solvents like $\mathrm{MeCN}$ and $\mathrm{MeOH}$. With the exception of 1B, which contains a 2-acetylphenolate ligand, the FTIR spectrum of each complex exhibits a $\mathrm{v}(\mathrm{O}-\mathrm{H})$ feature arising from the distal hydroxyl group, indicating that the HQ ligands are monoanionic and coordinated to a single Fe center.

Crystals of 1A-D suitable for X-ray structure determination were obtained by layering concentrated $\mathrm{CH}_{2} \mathrm{Cl}_{2}$ solutions with either MeCN or pentane. Details concerning data collection and analysis are provided in Table 3, and selected bond distances and angles for 1A-D are shown in Table 1. As illustrated in Figure 1, each complex features a five-coordinate (5C) $\mathrm{Fe}(\mathrm{II})$ center bound to a facially coordinating ${ }^{P h} 2 \mathrm{Tp}$ ligand and bidentate $\mathrm{HL}^{\mathrm{A}-\mathrm{D}}$ group. The Fe- $\mathrm{N}_{\mathrm{Tp}}$ bonds exhibit an average distance of $2.14 \AA$ across the series, characteristic of highspin $(S=2)$ ferrous complexes. ${ }^{21 d}, 22$ The Fe1-O1 distances, which range between $1.927(1)$ and $1.961(1) \AA$, are also typical for iron(II)phenolate units in $5 \mathrm{C}$ complexes. ${ }^{23}$ 
NOT THE PUBLISHED VERSION; this is the author's final, peer-reviewed manuscript. The published version may be accessed by following the link in the citation at the bottom of the page.

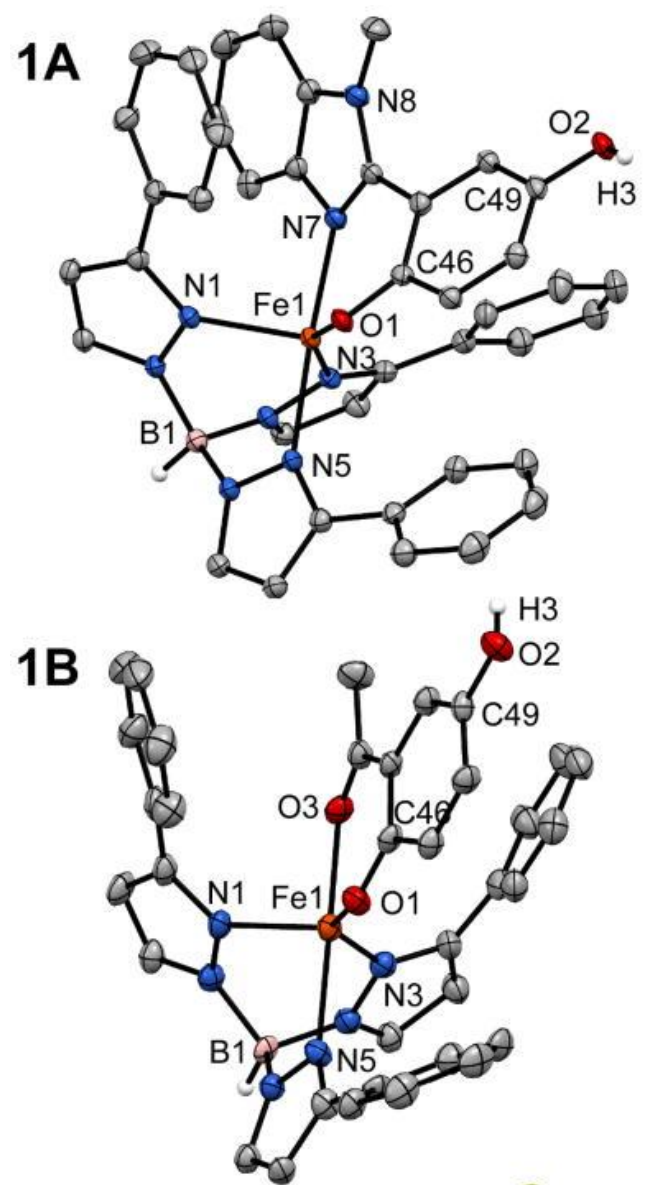

1D

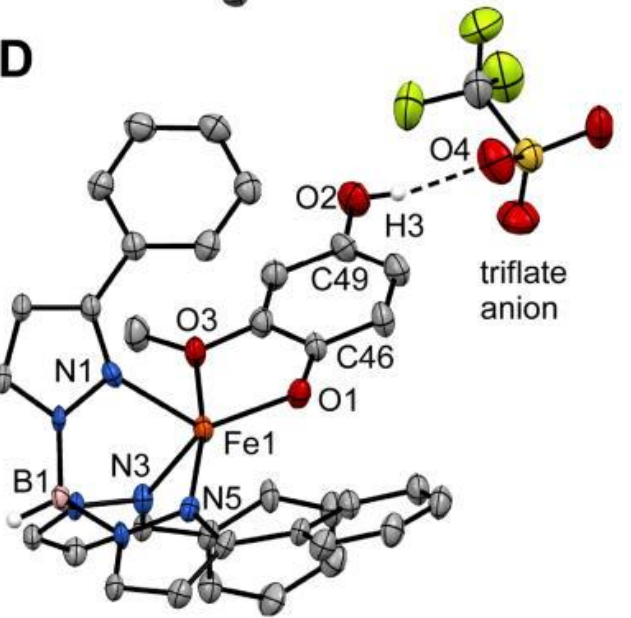

Figure 1 Thermal ellipsoid plots (50\% probability) derived from the $X$-ray structures of $\mathbf{1 A} \cdot \mathrm{CH}_{2} \mathrm{Cl}_{2}$ (top), $\mathbf{1} \mathbf{B} \cdot 2 \mathrm{CH}_{2} \mathrm{Cl}_{2}$ (middle), and $\mathbf{1} \mathbf{D} \cdot\left[\mathrm{HNEt}_{3}\right] \mathrm{OTf}$ (bottom). Non-coordinating solvent molecules and most hydrogen atoms have been omitted for clarity, as well as the Ph-rings at the 5-positions of the ${ }^{\mathrm{Ph}} 2 \mathrm{Tp}$ ligand. The $\mathrm{HNEt}_{3}{ }^{+}$ counter cation in the $\mathbf{1} \mathbf{D} \cdot\left[\mathrm{HNEt}_{3}\right] \mathrm{OTf}$ structure is not shown.

Dalton Transactions, Vol. 41, No. 39 (October 2012): pg. 12244-12253. DOI. This article is @ Royal Society of Chemistry and permission has been granted for this version to appear in e-Publications@Marquette. Royal Society of Chemistry does not grant permission for this article to be further copied/distributed or hosted elsewhere without the express permission from Royal Society of Chemistry. 
NOT THE PUBLISHED VERSION; this is the author's final, peer-reviewed manuscript. The published version may be accessed by following the link in the citation at the bottom of the page.

\begin{tabular}{|c|c|c|c|c|c|}
\hline & $1 \mathrm{~A} \cdot \mathrm{CH}_{2} \mathrm{Cl}_{2}$ & $1 \mathrm{~B} \cdot 2 \mathrm{CH}_{2} \mathrm{Cl}_{2}$ & $1 \mathrm{C}$ & $\mathrm{ID} \cdot\left[\mathrm{HNEt}_{3}\right] \mathrm{OTf}$ & IF \\
\hline $\mathrm{Fe}-\mathrm{Ol}$ & $1.961(1)$ & $1.937(4)$ & $1.927(1)$ & $1.931(3)$ & $1.893(1)$ \\
\hline Fe-N1 & $2.122(1)$ & $2.131(5)$ & $2.108(1)$ & $2.130(4)$ & $2.085(1)$ \\
\hline $\mathrm{Fe}-\mathrm{N} 3$ & $2.148(2)$ & $2.089(5)$ & $2.093(1)$ & $2.129(4)$ & $2.085(1)$ \\
\hline Fe-N5 & $2.147(2)$ & $2.185(5)$ & $2.228(1)$ & $2.186(4)$ & $2.285(1)$ \\
\hline $\mathrm{Fe}-\mathrm{L} \stackrel{\mathrm{a}}{\underline{a}}$ & $2.139(2)$ & $2.079(4)$ & $2.103(1)$ & $2.317(3)$ & $2.341(2)$ \\
\hline $\mathrm{O}-\mathrm{C} 46$ & $1.341(2)$ & $1.303(7)$ & $1.304(2)$ & $1.337(6)$ & $1.338(2)$ \\
\hline $\mathrm{O} 2-\mathrm{C} 49$ & $1.370(2)$ & $1.370(7)$ & & $1.371(6)$ & $1.390(2)$ \\
\hline $\mathrm{Ol}-\mathrm{Fe}-\mathrm{Nl}$ & $110.64(5)$ & $129.5(2)$ & $128.04(5)$ & $128.5(2)$ & $134.21(6)$ \\
\hline Ol-Fe-N3 & $153.34(5)$ & $139.9(2)$ & $140.01(5)$ & $130.0(2)$ & $131.98(6)$ \\
\hline Ol-Fe-N5 & $94.78(5)$ & $97.9(2)$ & $100.61(4)$ & $115.6(1)$ & $101.45(5)$ \\
\hline Ol-Fe-LX & $88.90(5)$ & $86.4(2)$ & $85.28(4)$ & $75.7(1)$ & $89.04(5)$ \\
\hline N1-Fe-N3 & $95.65(6)$ & $90.6(2)$ & $91.50(4)$ & $94.2(1)$ & $93.61(5)$ \\
\hline N1-Fe-N5 & $92.11(5)$ & $90.2(2)$ & $88.25(4)$ & $89.4(2)$ & $85.41(5)$ \\
\hline N3-Fe-N5 & $79.38(6)$ & $81.2(2)$ & $84.39(4)$ & $85.6(2)$ & $83.65(5)$ \\
\hline $\mathrm{L}_{\mathrm{X}}-\mathrm{Fe}-\mathrm{Nl}$ & $90.69(6)$ & $87.4(2)$ & $91.32(4)$ & $85.3(1)$ & $89.01(5)$ \\
\hline $\mathrm{L}_{\mathrm{X}}-\mathrm{Fe}-\mathrm{N} 3$ & $95.37(6)$ & $95.3(2)$ & $88.47(4)$ & $84.5(1)$ & $87.53(5)$ \\
\hline $\mathrm{LX}_{\mathrm{X}}-\mathrm{Fe}-\mathrm{N} 5$ & $174.27(6)$ & $175.7(2)$ & $172.83(4)$ & $168.4(1)$ & $169.24(5)$ \\
\hline$\tau$-value $\underline{b}$ & 0.35 & 0.60 & 0.55 & 0.64 & 0.58 \\
\hline
\end{tabular}

Table 1 Selected Bond Distances $(\AA)$ and Bond Angles (deg) from the X-ray Structures of Monoiron(II) Hydroquinonate Complexes 1A-D and 1F.

${ }^{a} \mathrm{~L}$ is the $\mathrm{N}$ or $\mathrm{O}$ atom of the pendant donor of the $\mathrm{HQ}$ anion.

${ }^{b}$ For a definition of the $T$-value, see reference ${ }^{24}$. A five-coordinate complex with ideal square-pyramidal geometry would have a T-value of 0.0 , while those with ideal trigonal bipyramidal geometry would have a value of 1.0 .

Dalton Transactions, Vol. 41, No. 39 (October 2012): pg. 12244-12253. DOI. This article is @ Royal Society of Chemistry and permission has been granted for this version to appear in e-Publications@Marquette. Royal Society of Chemistry does not grant permission for this article to be further copied/distributed or hosted elsewhere without the express permission from Royal Society of Chemistry. 
NOT THE PUBLISHED VERSION; this is the author's final, peer-reviewed manuscript. The published version may be accessed by following the link in the citation at the bottom of the page.

\begin{tabular}{|c|c|c|c|c|c|c|c|}
\hline & $1 \mathrm{~A} \cdot \mathrm{CH}_{2} \mathrm{Cl}_{2}$ & $1 \mathrm{~B} \cdot 2 \mathrm{CH}_{2} \mathrm{Cl}_{2} \stackrel{\mathrm{a}}{-}$ & $1 \mathrm{C}$ & $\mathrm{ID} \cdot\left[\mathrm{HNE} \mathrm{t}_{3}\right] \mathrm{OTf}$ & $\mathrm{lF}$ & $2 \mathrm{E} \cdot 2 \mathrm{E} \mathrm{t}_{2} \mathrm{O}$ & {$[2 \mathrm{~F}(\mathrm{MeCN})] \cdot 2 \mathrm{DCE} \underline{\underline{b}}$} \\
\hline empirical formula & $\mathrm{C}_{60} \mathrm{H}_{4} 7 \mathrm{BCl}_{2} \mathrm{FeN}_{8} \mathrm{O}_{2}$ & $\mathrm{C}_{55} \mathrm{H}_{45} \mathrm{BCl}_{4} \mathrm{FeN}_{6} \mathrm{O}_{3}$ & $\mathrm{C}_{53} \mathrm{H}_{41} \mathrm{BFeN}_{6} \mathrm{O}_{2}$ & $\mathrm{C}_{59} \mathrm{H}_{57} \mathrm{BF}_{3} \mathrm{FeN}_{7} \mathrm{O}_{6} \mathrm{~S}$ & $\mathrm{C}_{68} \mathrm{H}_{55} \mathrm{BFeN}_{8} \mathrm{O}_{2}$ & $\mathrm{C}_{106} \mathrm{H}_{96} \mathrm{~B}_{2} \mathrm{Fe}_{2} \mathrm{~N}_{12} \mathrm{O}_{6}$ & $\mathrm{C}_{104} \mathrm{H}_{8} \mathrm{~B}_{2} \mathrm{Cl}_{4} \mathrm{Fe}_{2} \mathrm{~N}_{13} \mathrm{O}_{2}$ \\
\hline formula weight & 1049.62 & 1046.46 & 860.58 & 1115.84 & 1082.86 & 1767.27 & 1826.02 \\
\hline crystal system & Monoclinic & Orthorhombic & Monoclinic & Triclinic & Monoclinic & Triclinic & Monoclinic \\
\hline space group & $P 2_{1 / c}$ & $P 2_{1}{ }^{2}{ }_{1}{ }_{1}$ & $P 2_{1} / n$ & $P-1$ & $P 2_{1} / c$ & $P-1$ & $P_{n}$ \\
\hline$a, \AA$ & $14.5859(5)$ & $11.2362(4)$ & $10.4129(2)$ & $9.6832(4)$ & $17.8034(7)$ & $9.6359(10)$ & $13.4895(3)$ \\
\hline$b, \AA$ & $13.6416(4)$ & $17.7643(6)$ & $30.8300(5)$ & $9.8868(5)$ & $22.3235(10)$ & $13.4413(14)$ & $10.0544(3)$ \\
\hline c. $\AA$ & $25.2090(8)$ & $25.2782(8)$ & $13.1758(2)$ & $28.3671(15)$ & $13.6123(6)$ & $18.205(2)$ & $32.9607(9)$ \\
\hline$\alpha, \operatorname{deg}$ & 90 & 90 & 90 & $85.740(4)$ & 90 & $95.633(9)$ & 90 \\
\hline$\beta, \operatorname{deg}$ & $93.779(3)$ & 90 & $90.634(2)$ & $86.952(4)$ & $99.746(4)$ & $105.298(10)$ & $96.806(3)$ \\
\hline$\gamma, \operatorname{deg}$ & 90 & 90 & 90 & $81.003(4)$ & 90 & $99.002(9)$ & 90 \\
\hline$V, A^{3}$ & $5005.0(3)$ & $5045.6(3)$ & $4229.6(1)$ & $2672.5(2)$ & $5331.9(4)$ & $2222.1(4)$ & $4438.9(2)$ \\
\hline$z$ & 4 & 4 & 4 & 2 & 4 & 1 & 2 \\
\hline$D_{\text {calc }}, g / \mathrm{cm}^{3}$ & 1.393 & 1.351 & 1.351 & 1.387 & 1.349 & 1.321 & 1.342 \\
\hline$\lambda, \AA$ & 1.5418 & 1.5418 & 0.7107 & 1.5418 & 0.7107 & 1.5418 & 1.5418 \\
\hline$\mu, \mathrm{mm}^{-1}$ & 3.831 & 4.518 & 0.408 & 3.209 & 0.340 & 3.131 & 4.018 \\
\hline$\theta$-range, deg & 7 to 148 & 7 to 148 & 7 to 59 & 9 to 148 & 7 to 59 & 7 to 148 & 7 to 148 \\
\hline reflections collected & 35336 & 19096 & 58359 & 15029 & 62124 & 15573 & 23318 \\
\hline independent reflections & $9913\left[R_{\text {int }}=0.0382\right]$ & $8984\left[R_{\text {int }}=0.0435\right]$ & $10931\left[R_{\text {int }}=0.0402\right]$ & 15029 & $13600\left[R_{\text {int }}=0.0409\right]$ & $8687\left[R_{\text {int }}=0.0622\right]$ & $12059\left[R_{\text {int }}=0.0406\right]$ \\
\hline data / restraints / parameters & $9913 / 0 / 672$ & $8984 / 0 / 634$ & $10931 / 0 / 569$ & $15029 / 0 / 709$ & $13600 / 0 / 731$ & $8687 / 24 / 569$ & $12059 / 31 / 1132$ \\
\hline GOF (on $\left.F^{2}\right)$ & 1.041 & 1.103 & 1.027 & 1.074 & 1.058 & 1.026 & 1.024 \\
\hline$R 1 / w R 2(I>2 \sigma(I)) \subseteq$ & $0.0354 / 0.0891$ & $0.0814 / 0.2410$ & $0.0375 / 0.0891$ & $0.0864 / 0.2278$ & $0.0414 / 0.1005$ & $0.0718 / 0.1807$ & $0.0638 / 0.1662$ \\
\hline$R 1 / w R 2$ (all data) $\subseteq$ & $0.0449 / 0.0954$ & $0.0838 / 0.2437$ & $0.0462 / 0.0953$ & $0.1008 / 0.2402$ & $0.0552 / 0.1083$ & $0.1152 / 0.2227$ & $0.0821 / 0.1826$ \\
\hline
\end{tabular}

Table 3 Summary of X-ray Crystallographic Data Collection and Structure

Refinement.

a One of the solvate molecules in $\mathbf{1 B} \cdot 2 \mathrm{CH}_{2} \mathrm{Cl}_{2}$ is only partially $(77 \%)$ populated.

${ }^{b}$ One of the solvate molecules in $[\mathbf{2 F}(\mathbf{M e C N})] \cdot 2 \mathrm{DCE}$ is only partially $(68 \%)$

populated.

${ }^{c} R 1=\Sigma|| F_{\mathrm{o}}|-| F_{\mathrm{c}}|| / \Sigma\left|F_{\mathrm{o}}\right| ; w R 2=\left[\Sigma w\left(F_{\mathrm{o}}^{2}-F_{\mathrm{c}}^{2}\right)^{2} / \Sigma w\left(F_{\mathrm{o}}^{2}\right)^{2}\right]^{1 / 2}$

The coordination geometry of $\mathbf{1 A}$ is intermediate between square pyramidal and trigonal bipyramidal $\left(T=0.35^{24}\right)$, and the $\mathrm{HL}^{\mathrm{A}}$ ligand adopts a twisted conformation with a dihedral angle of $35^{\circ}$ between the planes of the HQate and benzimidazolyl rings (Figure 1). This orientation is likely the result of $n$-stacking interactions between the benzimidazolyl moiety and a 3-phenyl substituent of the ${ }^{\mathrm{Ph} 2} \mathrm{Tp}$ ligand, in addition to steric repulsion between the HQate ring and a second phenyl group. Compared to $\mathbf{1 A}$, the structures of $\mathbf{1 B}$ and $\mathbf{1 C}$ lie much further towards the trigonal-bipyramidal limit ( $T=0.60$ and 0.55 , respectively) with the acetyl group in an axial position trans to a pyrazole donor (N5). The metric parameters for 1B and 1C are nearly identical, suggesting that the structural effects of the para hydroxyl group are minimal. The 01-C46 distances in 1B and 1C are shorter than the corresponding distance in $\mathbf{1 A}$ (1.303 vs. $1.341 \AA$; Table 1 ) due to delocalization of the negative charge onto the 2-acetyl group. and permission has been granted for this version to appear in e-Publications@Marquette. Royal Society of Chemistry does not grant permission for this article to be further copied/distributed or hosted elsewhere without the express permission from Royal Society of Chemistry. 
The 01-C46 bond of the acetophenone-derived ligands therefore acquires some double-bond character, whereas the twisted conformation of the $\mathrm{HL}^{\mathrm{A}}$ ligand indicates a lack of electronic conjugation between the n-systems.

In contrast to the $\mathrm{HL}^{\mathrm{A}-\mathrm{C}}$ donors, the 2-methoxyhydroquinonate ligand $\left(H L^{D}\right)$ in 1D forms a five-membered ring chelate with the Fe(II) center. This fact, coupled with the intrinsically weak donating ability of methoxy substituents, results in a rather lengthy Fe1-O3 distance of 2.317(3) $\AA$. Thus, in certain respects, 1D can be considered to possess an intermediate coordination number between 4 and 5 . As evidence, the $\mathrm{O} 1-\mathrm{Fe} 1-\mathrm{N} 5$ angle increases from an average of $97.8^{\circ}$ in $\mathbf{1 A - C}$ to $115.6^{\circ}$ in $1 \mathrm{D}$ (with a corresponding decrease in the $03-\mathrm{Fe} 1-\mathrm{N}_{\mathrm{Tp}}$ angles), as the HQate donor shifts out of the equatorial plane (Table 1). Thus, if the weakly-bound $-\mathrm{OCH}_{3}$ group is ignored, 1D appears to adopt a distorted trigonal pyramidal geometry with the $\mathrm{O} 1$ donor in the axial position. Notably, complex 1D co-crystallizes with one equivalent of [ $\left.\mathrm{HNEt}_{3}\right]$ OTf salt, and the triflate anion participates in a hydrogenbonding interaction with the distal $-\mathrm{OH}$ group in the solid state (Figure 1 ; the $02 \cdots 04$ distance is 2.782(6)). This feature is reminiscent of acid/base interactions between $\mathrm{HQ}$ substrates and conserved secondsphere residues that have been proposed to play an important role in HQDO catalysis. ${ }^{9 b}, 12 a$

The diiron(II) $\mu-L^{x}$ complexes were never observed in preparations of 1A-D, and we initially attributed the lack of dinuclear side-products to the steric demands of the ${ }^{\mathrm{Ph} 2} \mathrm{Tp}$ ligand. To evaluate this hypothesis, we generated the compound 2,5dimethoxyhydroquinone $\left(\mathrm{H}_{2} \mathrm{~L}^{\mathrm{E}}\right)$, which is capable of coordinating two metal centers in a bidentate fashion. Interestingly, use of this ligand provides the diiron(II) complex 2E as the only isolated product even when the reactants are mixed in equimolar ratios, thereby proving that the ${ }^{\mathrm{Ph} 2} \mathrm{Tp}$ framework is capable of supporting dinuclear complexes. The $X$-ray structure of $\mathbf{2 E}$ is shown in Figure 2 and key metric parameters are listed in the caption. The complex is centrosymmetric with an Fe...Fe distance of $8.15 \AA$. The Fe-O/N distances of $\mathbf{2 E}$ are nearly identical to those of the analogous monoiron(II) complex 1D, although the position of the HQate ligand with respect to the $\mathrm{N}_{T p}$ donors is somewhat different (e.g., $\angle \mathrm{O} 1-\mathrm{Fe} 1-\mathrm{N} 5=98.1(2)^{\circ}$ and $115.6(1)^{\circ}$ in $\mathbf{2 E}$ and 1D, respectively). The fact that the 2,5-dimethoxylhydroquinonate 
ligand exclusively yields $\mathbf{2 E}$, whereas ligands $\mathrm{HL}^{\mathrm{A}-\mathrm{D}}$ favor monomeric species, suggests that the thermodynamic benefit of bidentate chelation at both $\mathrm{Fe}(\mathrm{II})$ centers is able to overcome the steric barrier to dimerization.

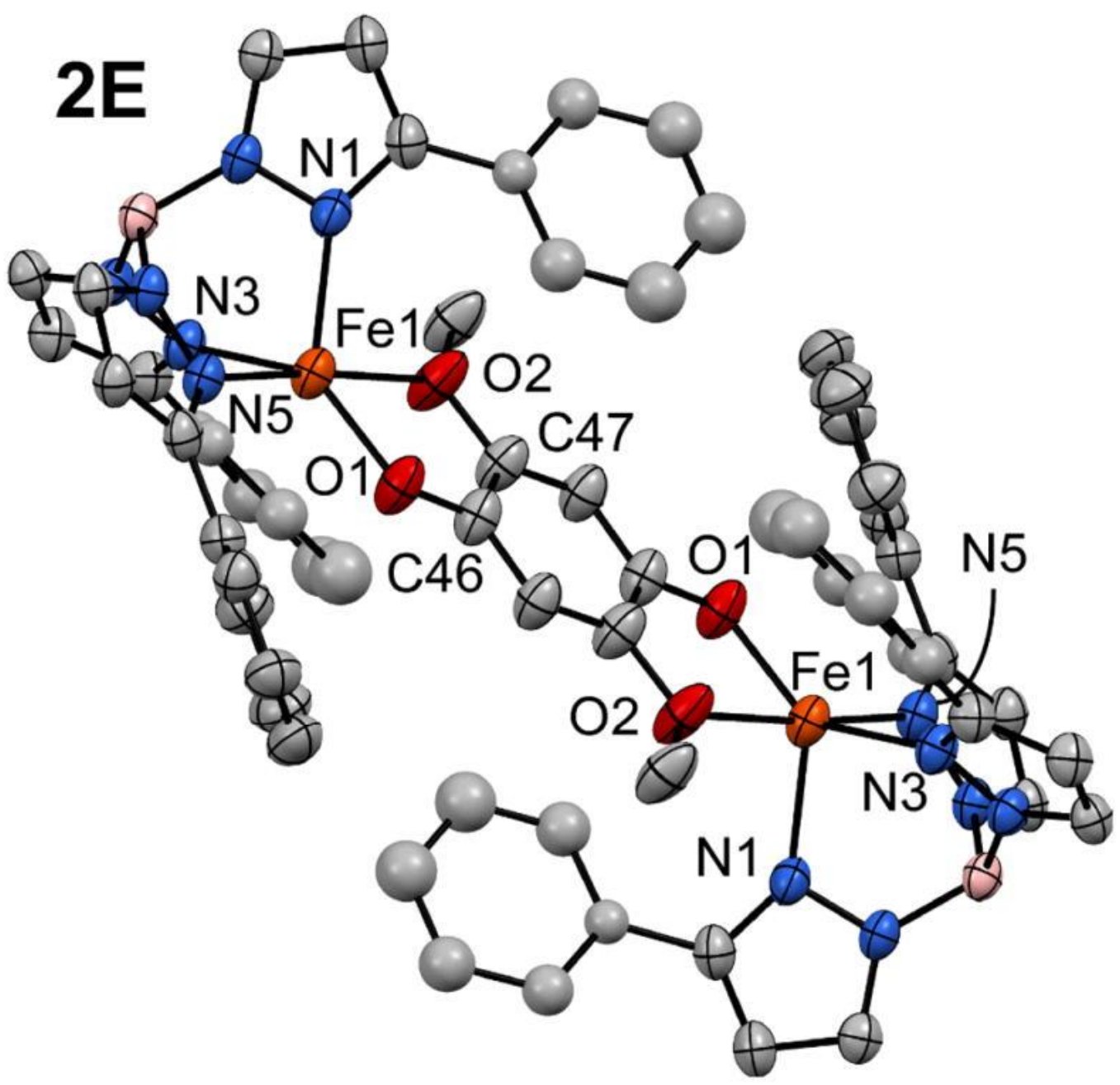

Figure 2 Thermal ellipsoid plot (50\% probability) derived from the X-ray structure of $\mathbf{2 E} \cdot \mathrm{CH}_{2} \mathrm{Cl}_{2}$. Non-coordinating solvent molecules and hydrogen atoms have been omitted for clarity, in addition to Ph-rings at the 5-positions of the ${ }^{\mathrm{Ph} 2} \mathrm{Tp}$ ligand. Ellipsoids are not shown for four Ph rings due to disorder. Selected bond lengths $(\AA)$ and angles $\left({ }^{\circ}\right)$ [note: the complex is centrosymmetric]: Fe1-01 1.904(3), Fe1-O2 2.328(3), Fe1-N1 2.107(4), Fe1-N3 2.108(3), Fe1-N5 2.213(4), O1-C46 1.329(5), O2C47 1.388(6); O1-Fe1-O2 75.2(1), O1-Fe1-N1 131.9(2), O1-Fe1-N3 138.7(2), O1Fe1-N5 98.9(1), O2-Fe1-N1 91.8(2), O2-Fe1-N3 97.9(1), O2-Fe1-N5 174.1(1), N1Fe1-N3 88.3(1), N1-Fe1-N5 91.8(1), N3-Fe1-N5 86.9(1). and permission has been granted for this version to appear in e-Publications@Marquette. Royal Society of Chemistry does not grant permission for this article to be further copied/distributed or hosted elsewhere without the express permission from Royal Society of Chemistry. 


\section{Fe(II) Complexes with an Untethered Hydroquinonate Ligand - Synthesis and Solid State Structures}

As noted in the Introduction, several HQDOs oxidize "untethered" HQS that lack additional metal-coordinating groups. To replicate the monodentate binding mode of these $\mathrm{HQ}$ substrates, we employed the ligand 2,6-dimethylhydroquinone $\left(\mathrm{H}_{2} \mathrm{~L}^{\mathrm{F}}\right)$. Reaction of $\mathrm{H}_{2} \mathrm{~L}^{\mathrm{F}}$ with equimolar amounts of $\mathrm{K}\left({ }^{\mathrm{Ph} 2} \mathrm{Tp}\right), \mathrm{FeCl}_{2}$, and $\mathrm{NaOMe}$ in $\mathrm{MeCN}$ generates a bright orange solid, which was recrystallized by slow diffusion of MeCN into a concentrated 1,2-dichloroethane (DCE) solution. X-ray analysis of the crystals revealed a diiron(II) structure with the formulation, $\left[\mathrm{Fe}_{2}\left({ }^{\mathrm{Ph} 2} \mathrm{Tp}\right)_{2}\left(\mu-\mathrm{L}^{\mathrm{F}}\right)(\mathrm{MeCN})\right](\mathbf{2} \mathbf{F}(\mathrm{MeCN})$; Figure 3). Unlike 2E, the Fe(II) centers in $\mathbf{2} \mathbf{F}(\mathrm{MeCN})$ are not equivalent: $\mathrm{Fe} 2$ is $4 \mathrm{C}$ due to steric hindrance from the methyl substituents of the bridging $L^{F}$ dianion, and $\mathrm{Fe} 1$ is $5 \mathrm{C}$ with an additional solvent $\mathrm{MeCN}$ ligand. The Fe1 center exhibits a distorted trigonal bipyramidal coordination geometry $(\mathrm{T}=$ $0.58)$, while the $\mathrm{Fe} 2$ geometry is best described as trigonal pyramidal $\left(\angle \mathrm{O} 2-\mathrm{Fe} 2-\mathrm{N}_{\mathrm{Tp}}=125 \pm 5^{\circ}\right)$. The low $\mathrm{Fe} 2$ coordination number leads to relatively short metal-ligand bond lengths, especially the Fe2-O2 distance of 1.784(6) $\AA$ (see Figure 3 caption for additional metric parameters). The high-spin Fe ions are separated by $8.72 \AA$. While the initial synthesis of $\mathbf{2} \mathbf{F}$ employed equimolar amounts of reagents, the complex can also be prepared in greater yield by using only 0.5 equivalent of $\mathrm{H}_{2} \mathrm{~F}^{\mathrm{F}}$.

Dalton Transactions, Vol. 41, No. 39 (October 2012): pg. 12244-12253. DOI. This article is @ Royal Society of Chemistry and permission has been granted for this version to appear in e-Publications@Marquette. Royal Society of Chemistry does not grant permission for this article to be further copied/distributed or hosted elsewhere without the express permission from Royal Society of Chemistry. 


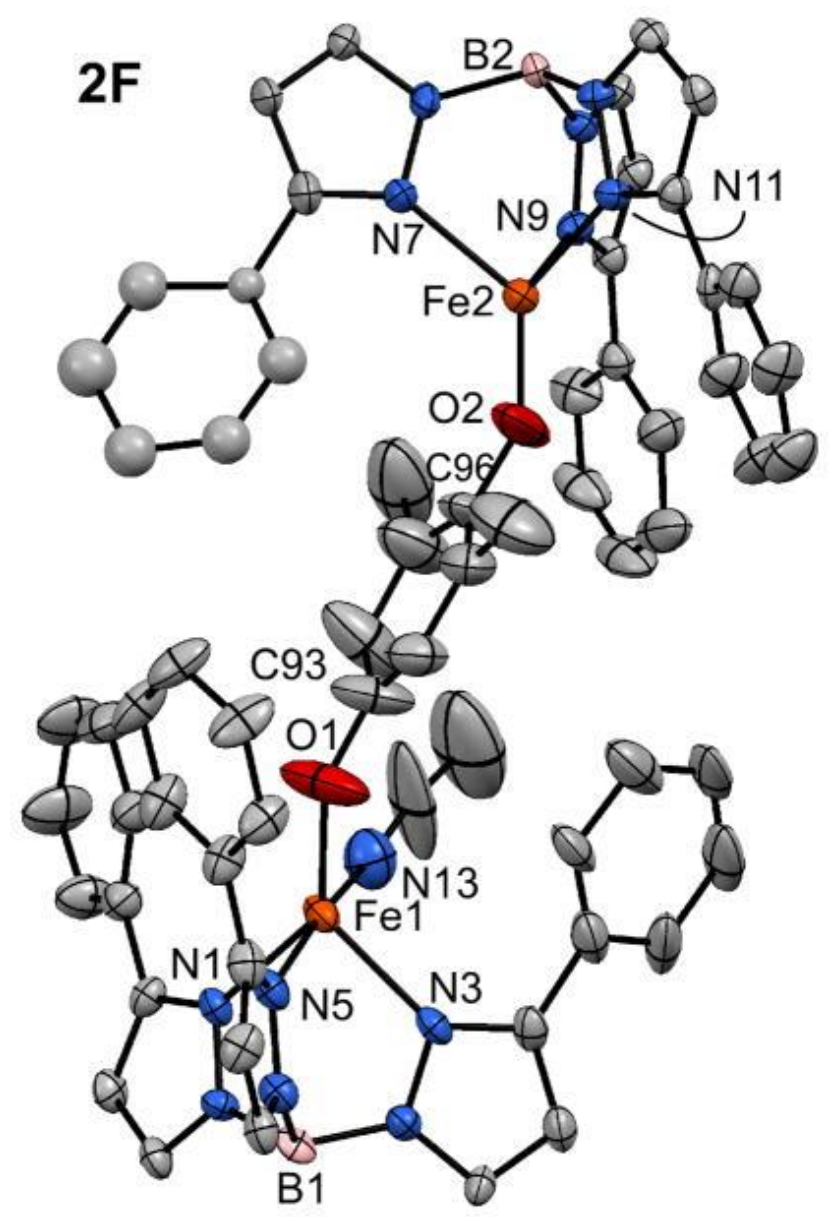

Figure 3 Thermal ellipsoid plot (50\% probability) derived from the X-ray structure of $[2 \mathrm{~F}(\mathbf{M e C N})] \cdot 2 \mathrm{DCE}$. Non-coordinating solvent molecules, hydrogen atoms, and $\mathrm{Ph}-$ rings at the 5-positions of the ${ }^{\mathrm{Ph} 2} \mathrm{Tp}$ ligand have been omitted for clarity. Selected bond lengths $(\AA)$ : Fe1-O1 1.852(6), Fe1-N1 2.111(5), Fe1-N3 2.136(6), Fe1-N5 2.187(5), Fe1-N13 2.289(8), O1-C93 1.348(10), Fe2-O2 1.784(6), Fe2-N7 2.105(5), Fe2-N9 2.119(5), Fe2-N11 2.136(5), O2-C96 1.352(10).

In an effort to prevent formation of $\mathbf{2} \mathbf{F}(\mathrm{MeCN})$, one equivalent of 3,5-diphenylpyrazole ( ${ }^{\mathrm{Ph} 2} \mathrm{pz}$ ) was included in the reaction mixture described above. Under these conditions, the reaction provided a yellow product that was recrystallized by DCE/pentane layering. X-ray diffraction analysis revealed that the crystals contain the $5 \mathrm{C}$ monoiron(II) complex, $\left[\mathrm{Fe}\left({ }^{\mathrm{Ph} 2} \mathrm{Tp}\right)\left(\mathrm{HL}^{\mathrm{F}}\right)\left({ }^{\mathrm{Ph} 2} \mathrm{pz}\right)\right]\left[\mathbf{1} \mathbf{F}\left({ }^{\mathrm{Ph} 2} \mathrm{pz}\right)\right]$. As shown in Figure $4,1 \mathrm{~F} 1 \mathrm{~F}\left({ }^{\mathrm{Ph} 2} \mathrm{pz}\right)$ features a trigonal bipyramidal coordination geometry $(T=0.58)$ with the HQate and ${ }^{\mathrm{Ph} 2} \mathrm{pz}$ donors in equatorial and axial positions, respectively. These two ligands form an intramolecular hydrogen-bond that closes a five-membered ring, as evident in the

Dalton Transactions, Vol. 41, No. 39 (October 2012): pg. 12244-12253. DOl. This article is (C Royal Society of Chemistry and permission has been granted for this version to appear in e-Publications@Marquette. Royal Society of Chemistry does not grant permission for this article to be further copied/distributed or hosted elsewhere without the express permission from Royal Society of Chemistry. 
O1 $\cdots$ N8 distance of $2.840(2) \AA$ and $01 \cdots H 7$ distance of $2.17(2) \AA$ (the $\mathrm{H} 2$ and $\mathrm{H} 7$ atoms were found objectively and refined). The Fe1-O1 bond distance of 1.893(1) is shorter than the corresponding distances in the tethered complexes $\mathbf{1 A - D}$, whereas the axial ${ }^{\mathrm{Ph}} 2 \mathrm{pz}$ ligand is weakly bound with an Fe1-N7 distance of 2.341(2) $\AA$ (Table 1). As expected, $\mathrm{HL}^{\mathrm{F}}$ coordinates to the $\mathrm{Fe}(\mathrm{II})$ center via the more stericallyaccessible $\mathrm{O}$-atom at the 4-position of the $\mathrm{HQ}$. Without the constraint of a pendant ligand, the HQate ring in $\mathbf{1 F}\left({ }^{\mathrm{Ph} 2} \mathrm{pz}\right)$ rotates away from the Fe center, as signified by the large Fe1-O1-C46 bond angle of $148.7(1)^{\circ}$ (compared values of $125 \pm 5^{\circ}$ for 1A-1D).

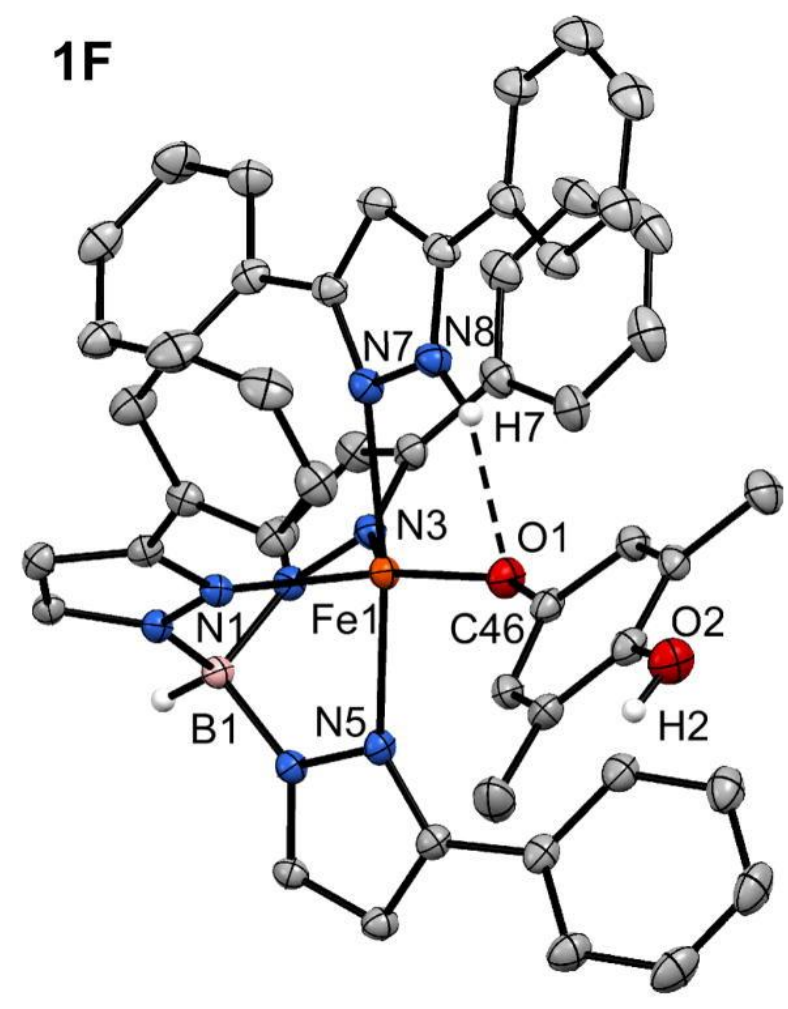

Figure 4 Thermal ellipsoid plot (50\% probability) derived from the X-ray structure of 1F. Hydrogen atoms and Ph-rings at the 5-positions of the ${ }^{\mathrm{Ph}} 2 \mathrm{Tp}$ ligand have been omitted for clarity. Selected bond lengths and angles are provided in Table 1.

\section{Spectroscopic and Electrochemical Properties of $\mathrm{Fe}(\mathrm{II})$-Hydroquinonate Complexes}

Electronic absorption spectra of complexes $\mathbf{1 A - D}$ and $\mathbf{1 F}$ in $\mathrm{CH}_{2} \mathrm{Cl}_{2}$ are shown in Figure 5. Complexes 1B and $\mathbf{1 C}$ are both brightly

Dalton Transactions, Vol. 41, No. 39 (October 2012): pg. 12244-12253. DOI. This article is @ Royal Society of Chemistry and permission has been granted for this version to appear in e-Publications@Marquette. Royal Society of Chemistry does not grant permission for this article to be further copied/distributed or hosted elsewhere without the express permission from Royal Society of Chemistry. 
colored due a weak absorption manifold $\left(\varepsilon \sim 0.7 \mathrm{mM}^{-1} \mathrm{~cm}^{-1}\right)$ in the visible region and an intense peak in the near-UV $\left(\varepsilon \sim 5.5 \mathrm{mM}^{-1} \mathrm{~cm}^{-1}\right)$. The application of time-dependent density functional theory (TD-DFT) to $\mathbf{2 B}$ revealed that the lower-energy band arises from an $\mathrm{Fe}(\mathrm{II}) \rightarrow \mathrm{HL}^{\mathrm{B}}$ MLCT transition in which the acceptor molecular orbital (MO) has primarily acetyl $\left(\mathrm{C}=\mathrm{O}^{*}\right)$ character. The higher-energy feature is assigned to a $\mathrm{HL}^{\mathrm{B}}$-based $\Pi \rightarrow \Pi^{*}$ transition (see ESI† for details concerning the TD-DFT calculations). While 1A does not exhibit visibleregion MLCT transitions like $\mathbf{1 B}$ and $\mathbf{1 C}$, a very intense ligand-based $\Pi \rightarrow \Pi^{*}$ band is observed with $\lambda_{\max }=369 \mathrm{~nm}$ (Figure 5 ). In contrast, complexes containing ligands derived from methoxy- and alkylsubstituted HQs $\left(\mathrm{H}_{2} \mathrm{~L}^{\mathrm{D}-\mathrm{F}}\right.$ ) have pale yellow colors due to broad UV absorption features that tail into the visible region (Figures 5 and S1, ESI + ).

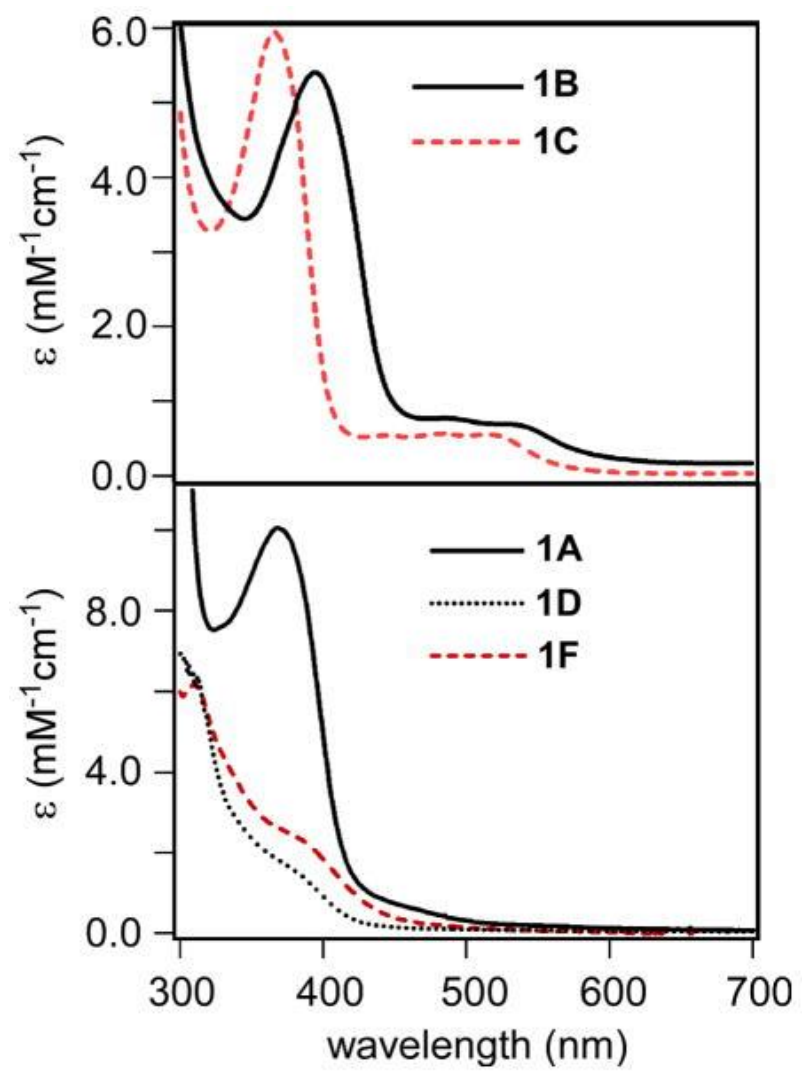

Figure 5 Electronic absorption spectra of complexes $\mathbf{1 A - D}$ and $\mathbf{1 F}$ in $\mathrm{CH}_{2} \mathrm{Cl}_{2}$ at room temperature. 
${ }^{1} \mathrm{H}$ NMR spectra of complexes 1A-1D and $\mathbf{1 F}$ in $\mathrm{CD}_{2} \mathrm{Cl}_{2}$ display paramagnetically-shifted signals characteristic of high-spin monoiron(II) centers (Figure S2, ESI + ). Peaks arising from the ${ }^{\mathrm{Ph} 2} \mathrm{Tp}$ supporting ligand are easily assigned by comparison to earlier literature reports (e.g., the signal from the 4-pyrzole protons consistently appears near 55 ppm). ${ }^{21 d,}$ 22a In each case, the resonance arising from the distal hydroxyl substituent was identified through $H / D$ exchange with a small amount of added $\mathrm{MeOH}-d_{4}$. These peaks appear downfield with chemical shifts of $23 \pm 3$ ppm, although the hydroxyl proton is observed at $59 \mathrm{ppm}$ in the 1D spectrum (Figure S2, ESI + ). The observation of paramagnetically-shifted $-\mathrm{OH}$ resonances confirms that the HQate ligands do not adopt bridging positions in solution.

The electrochemical behavior of the monoiron(II) complexes 1A-D and $\mathbf{1 F}$ were studied by cyclic voltammetry in $\mathrm{CH}_{2} \mathrm{Cl}_{2}$ or THF solutions containing $100 \mathrm{mM}$ [NBu $4 \mathrm{PF}_{6}$ as the supporting electrolyte. The cyclic voltammograms are displayed in Figure 6 and the results are summarized in Table 2 . All redox potentials are referenced to the ferrocenium/ferrocene couple ( $\mathrm{Fc}^{+} / \mathrm{Fc}$ ). Complexes 1A-C display quasi-reversible one-electron oxidation waves between -290 and -30 $\mathrm{mV}$ that correspond to the Fe(II/III) couple. The Fe redox potential of $\mathbf{1 A}$ is significantly lower than those of $\mathbf{1 B}$ and $\mathbf{1 C}$, reflecting the stronger donating ability of benzimidazolyl relative to acetyl groups. When the window is expanded to more positive potentials, both $\mathbf{1 A}$ and 1B exhibit a highly irreversible wave that likely corresponds to oxidation of the respective HQate ligands. The irreversible nature of the hydroquinonate-based oxidation is probably due to subsequent loss of the distal -OH proton to the surrounding medium. Notably, 1C is redox inactive are higher potentials, which is not surprising given that phenolates are intrinsically harder to oxidize than HQates. ${ }^{25}$ 
NOT THE PUBLISHED VERSION; this is the author's final, peer-reviewed manuscript. The published version may be accessed by following the link in the citation at the bottom of the page.

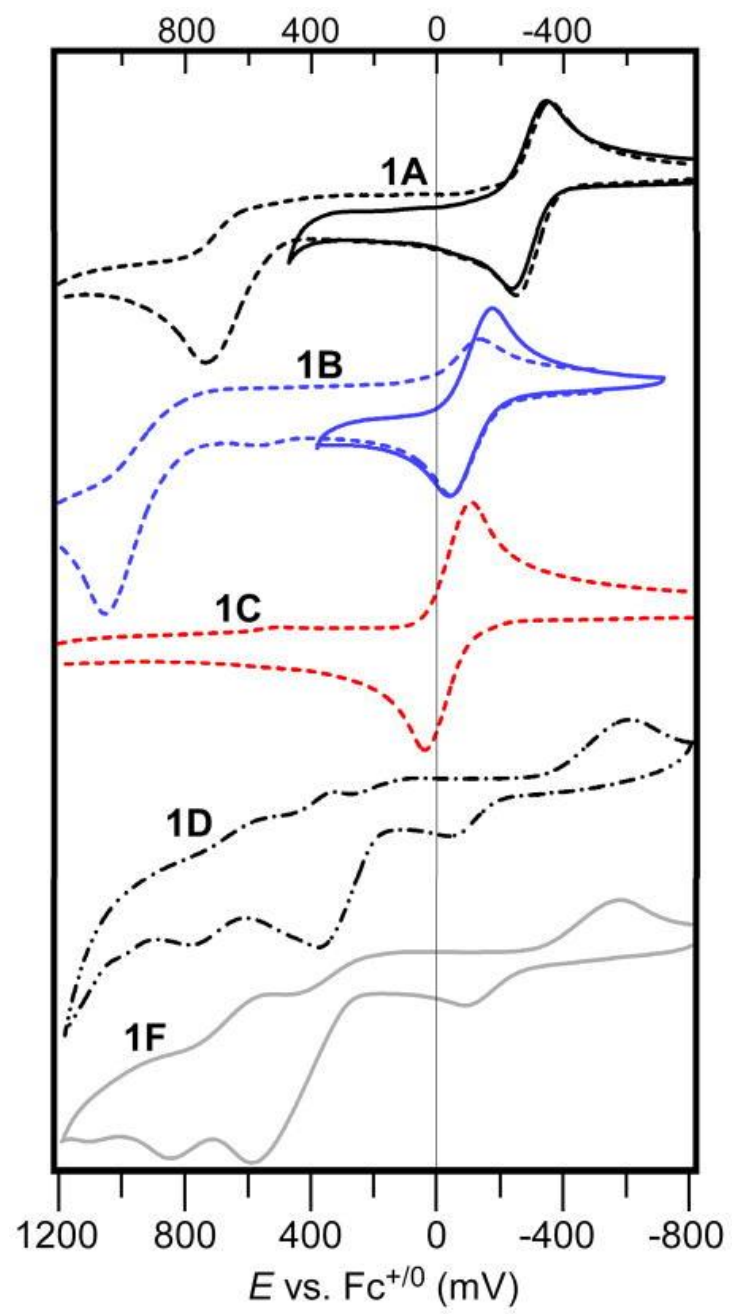

Figure 6 Cyclic voltammograms of $\mathbf{1 A - D}$ and 1F. Data was collected in $\mathrm{CH}_{2} \mathrm{Cl}_{2}$ $(\mathbf{1 A - C})$ or THF (1D and $\mathbf{1 F})$ with $100 \mathrm{mM}\left(\mathrm{NBu}_{4}\right) \mathrm{PF}_{6}$ as the supporting electrolyte and a scan rate of $100 \mathrm{mV} / \mathrm{s}$. Each voltammogram was initiated by the anodic sweep.

\begin{tabular}{c|c|l} 
complex & solvent & Redox Potentials (mV vs Fc \\
\hline IA & $\mathrm{CH}_{2} \mathrm{Cl}_{2}$ & $E_{1 / 2}(\Delta E)=-290(110) ; E_{\mathrm{p}, \mathrm{a}}=+740 \mathrm{mV}$ \\
IB & $\mathrm{CH}_{2} \mathrm{Cl}_{2}$ & $E_{1 / 2}(\Delta E)=-110(140) ; E_{\mathrm{p}, \mathrm{a}}=+1050 \mathrm{mV}$ \\
IC & $\mathrm{CH}_{2} \mathrm{Cl}_{2}$ & $E_{1 / 2}(\Delta E)=-30(150)$ \\
ID & $\mathrm{THF}$ & $E_{\mathrm{p}, \mathrm{a}}=-50,+370$, and $+780 \mathrm{mV}$ \\
IF & $\mathrm{THF}$ & $E_{\mathrm{p}, \mathrm{a}}=-100,+580$, and $+850 \mathrm{mV}$ \\
\hline
\end{tabular}

Table 2 Redox Potentials of Complexes 1A-D and 1F. ${ }^{a}$

${ }^{a}$ Conditions: Solutions contained $100 \mathrm{mM}\left(\mathrm{NBu}_{4}\right) \mathrm{PF}_{6}$; scan rate of $100 \mathrm{mV} \mathrm{s}^{-1}$ at room

Dalton Transactions, Vol. 41, No. 39 (October 2012): pg. 12244-12253. DOI. This article is @ Royal Society of Chemistry and permission has been granted for this version to appear in e-Publications@Marquette. Royal Society of Chemistry does not grant permission for this article to be further copied/distributed or hosted elsewhere without the express permission from Royal Society of Chemistry. 
NOT THE PUBLISHED VERSION; this is the author's final, peer-reviewed manuscript. The published version may be accessed by following the link in the citation at the bottom of the page.

temperature.

${ }^{\mathrm{b}} E_{1 / 2}$ and $\Delta E$ values are provided for (quasi)reversible processes; $E_{\mathrm{p}, \mathrm{a}}$ values are given for irreversible oxidation events.

As shown in Figure 6, reversible electrochemical processes were not observed in the cyclic voltammograms of 1D and 1F; instead, each complex displays a weak anonic wave $\left(E_{\mathrm{p}, \mathrm{a}}=-50\right.$ and $-100 \mathrm{mV}$ for 1D and 1F, respectively) that is assigned to one-electron oxidation of the Fe(II) center. The corresponding cathodic waves appear at much more negative potentials ( $E_{\mathrm{p}, \mathrm{c}} \sim-600 \mathrm{mV}$ in both cases), suggesting an irreversible change following oxidation to $\mathrm{Fe}$ (III). Additional irreversible events arising from HQate-based oxidation are evident at higher potentials for 1D and 1F (Table 2; Figure 6). As expected, the potential of the first HQate-based oxidation shifts to more negative potentials as the HQate substituents become more electron-donating: $E\left(\mathrm{HL}^{\mathrm{D}}\right)<E\left(\mathrm{HL}^{\mathrm{F}}\right)<E\left(\mathrm{HL}^{\mathrm{A}}\right)<E\left(\mathrm{HL}^{\mathrm{B}}\right)$. The ill-defined electrochemical behavior of $\mathbf{1 D}$ and $\mathbf{1 F}$ is likely a result of the greater conformational flexibility of their HQate ligands, which are not locked into a stable six-membered ring chelate like the $\mathrm{HL}^{\mathrm{A}-\mathrm{C}}$ ligands.

Given that complexes 1A-1C display reversible Fe(II/III) redox couples, we sought to examine the corresponding ferric species, $\mathbf{1} \mathbf{X}_{\mathbf{o x}}$, with spectroscopic methods. As shown in Figure 7, treatment of the $\mathrm{Fe}$ (II) complexes with one equivalent of a one-electron oxidant, such as acetylferrocenium or $\left[\mathrm{N}\left(\mathrm{C}_{6} \mathrm{H}_{4} \mathrm{Br}-4\right)_{3}\right]^{+}$, yields chromophores with broad, intense absorption features centered near $480 \mathrm{~nm}$. Based on literature precedents, ${ }^{26}$ these bands are confidently assigned to $\mathrm{HL}^{\mathrm{A}-}$ $\mathrm{C}_{\rightarrow} \mathrm{Fe}$ (III) LMCT transitions. The high intensities of the LMCT bands are indicative of strong Fe1-O1 covalency in the oxidized state, arising from overlap between the out-of-plane n-orbital of the phenolate ligand and the partially-occupied $\mathrm{Fe}(\mathrm{xy})$ orbital. ${ }^{27}$ EPR spectra of the oxidized species $\mathbf{1} \mathbf{A}_{\text {ox }}-\mathbf{1} \mathbf{C}_{\text {ox }}$ (Figure S3, ESI $\dagger$ ) each reveal an intense derivative-shaped feature at $g=4.3$ and a very weak peak near $g=$ 9.4, characteristic of rhombic high-spin Fe(III) centers.

Dalton Transactions, Vol. 41, No. 39 (October 2012): pg. 12244-12253. DOI. This article is @ Royal Society of Chemistry and permission has been granted for this version to appear in e-Publications@Marquette. Royal Society of Chemistry does not grant permission for this article to be further copied/distributed or hosted elsewhere without the express permission from Royal Society of Chemistry. 


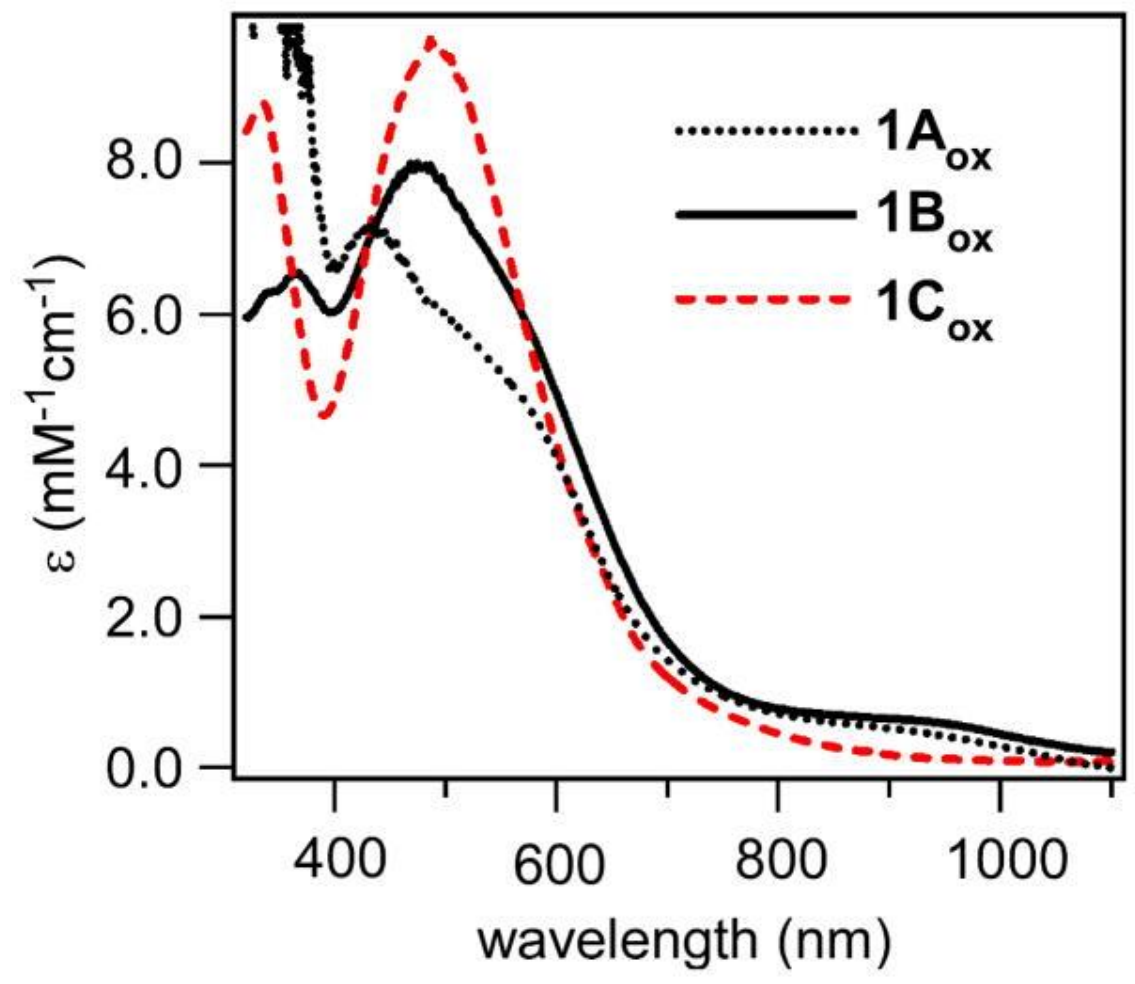

Figure 7 Electronic absorption spectra of $\mathbf{1} \mathbf{A}_{\mathbf{o x}}-\mathbf{- 1} \mathbf{C}_{\mathbf{o x}}$ in $\mathrm{CH}_{2} \mathrm{Cl}_{2}$ at room temperature. The $\mathbf{1} \mathbf{X}_{\mathbf{o x}}$ species were obtained by treating the $\mathrm{Fe}(\mathrm{II})$ precursors with one equivalent of acetylferrocenuium (1 $\left.\mathbf{1}_{\mathbf{o x}}\right)$ or $\left[\mathrm{N}\left(\mathrm{C}_{6} \mathrm{H}_{4} \mathrm{Br}-4\right)_{3}\right]^{+}\left(\mathbf{1} \mathbf{B}_{\mathbf{o x}}\right.$ and $\left.\mathbf{1} \mathbf{C}_{\mathbf{o x}}\right)$.

\section{Conclusions}

We have reported the synthesis and X-ray structure analysis of a series of monoiron(II) hydroquinonate complexes (1A-D and 1F) that represent the first crystallographically-characterized models of $\mathrm{Fe} / \mathrm{HQ}$ ate interactions in HQDO active sites. The spectroscopic and electrochemical properties of the complexes were also described. The models employed bidentate ("tethered") and monodentate ("untethered") HQate ligands, since HQDOs oxidize both types of substrates. Although HQate ligands are known to bridge multiple metal centers, the tethered ligands $\left(\mathrm{H}_{2} \mathrm{~L}^{\mathrm{A}-\mathrm{D}}\right)$ cleanly provided $5 \mathrm{C}$ mononuclear complexes supported by the tridentate ${ }^{\mathrm{Ph} 2} \mathrm{Tp}$ framework. It was possible, though, to obtain the diiron(II) complex $\mathbf{2 E}$ by inclusion of an additional donor substituent at the 5-position of the HQate ring. Compared to the bidentate HQates, the untethered ligand, $\mathrm{H}_{2} \mathrm{~L}^{\mathrm{F}}$, readily adopted a bridging position between $\mathrm{Fe}$ (II) centers, as evident in the facile formation of $\mathbf{2 F}$. Addition of one equivalent of free and permission has been granted for this version to appear in e-Publications@Marquette. Royal Society of Chemistry does not grant permission for this article to be further copied/distributed or hosted elsewhere without the express permission from Royal Society of Chemistry. 
pyrazole $\left({ }^{\mathrm{Ph} 2} \mathrm{pz}\right)$ to the reaction mixture, however, provided the complex 1F( $\left.{ }^{\mathbf{P h}} \mathbf{p z}\right)$ - the only structurally-characterized example of a monoiron(II) complex with an untethered HQate ligand reported to date. The stability of $\mathbf{1 F}\left({ }^{\mathbf{P h} \mathbf{2}} \mathbf{p z}\right)$ is undoubtedly enhanced by an intramolecular hydrogen bond between the HQate and ${ }^{\mathrm{Ph} 2} \mathrm{pz}$ ligands (Figure 4). While crystallographic studies of substrate-bound HQDOs are not currently available, structures of ECDO:substrate complexes have revealed similar hydrogen-bonding interactions between the deprotonated $\mathrm{O}$-atom of the catecholate ligand and second-sphere residues. ${ }^{2 a, 28}$

Thus, $\mathbf{1 F}\left({ }^{\mathbf{P h}} \mathbf{p z}\right)$ replicates important aspects of the enzymatic coordination environment. The results presented here provide a basis for future modeling studies of the HQDOs. As noted in the introduction, the non-innocent nature of HQate ligands is thought to play an important role in the HQDO mechanism. Indeed, the cyclic voltammograms of $\mathbf{1 A}$ and $\mathbf{1 B}$ reveal an irreversible wave that likely corresponds to HQate oxidation coupled to loss of the distal $-\mathrm{OH}$ proton. Detailed studies of the electron- and proton-transfer capabilities of our mono- and dinuclear HQate complexes are currently underway with the aim of generating novel Fe benzo(semi)quinone species. In addition, we will perform $\mathrm{O}_{2}$ reactivity studies to determine whether these excellent structural models also behave as functional models of the HQDOs.

\section{Experimental Section}

\section{Materials and Methods}

Unless otherwise noted, all reagents and solvents were purchased from commercial sources and used as received. Acetonitrile, dichloromethane, and tetrahydrofuran were purified and dried using a Vacuum Atmospheres solvent purification system. The synthesis and handling of air-sensitive materials were performed under inert atmosphere using a Vacuum Atmospheres Omni-Lab glovebox. The ligands $\mathrm{K}\left({ }^{\mathrm{Ph} 2} \mathrm{Tp}\right)^{29}$ and 2,5-dimethoxyhydroquinone $\left(\mathrm{H}_{2} \mathrm{~L}^{\mathrm{E}}\right)^{30}$ were prepared according to literature procedures.

Elemental analyses were performed at Midwest Microlab, LLC in Indianapolis, IN. UV-vis absorption spectra were obtained with an 
Agilent 8453 diode array spectrometer equipped with a cryostat from Unisoku Scientific Instruments (Osaka, Japan) for temperature control. Fourier-transform infrared (FTIR) spectra of solid samples were measured with a Thermo Scientific Nicolet iS5 FTIR spectrometer equipped with the iD3 attenuated total reflectance accessory. ${ }^{1} \mathrm{H}$ spectra were collected at room temperature with a Varian $400 \mathrm{MHz}$ spectrometer. EPR experiments were performed using a Bruker ELEXSYS E600 equipped with an ER4415DM cavity resonating at 9.63 $\mathrm{GHz}$, an Oxford Instruments ITC503 temperature controller, and an ESR-900 He flow cryostat. Electrochemical measurements were conducted in the glovebox with an epsilon EC potentiostat (iBAS) at a scan rate of $100 \mathrm{mV} / \mathrm{s}$ with $100 \mathrm{mM}\left(\mathrm{NBu}_{4}\right) \mathrm{PF}_{6}$. A three-electrode cell containing a $\mathrm{Ag} / \mathrm{AgCl}$ reference electrode, a platinum auxiliary electrode, and a glassy carbon working electrode was employed for cyclic voltammetric (CV) measurements. Under these conditions, the ferrocene/ferrocenium $\left(\mathrm{Fc}^{+/ 0}\right)$ couple has an $\mathrm{E}_{1 / 2}$ value of $+0.52 \mathrm{~V}$ in $\mathrm{CH}_{2} \mathrm{Cl}_{2}$ and $+0.61 \mathrm{~V}$ in $\mathrm{THF}$.

2-(1-methyl-1H-benzimidazol-2-yl)hydroquinone $\left(H_{2} L^{A}\right)$ To 2,5dihydroxybenzealdehyde $(690 \mathrm{mg}, 5.0 \mathrm{mmol}$ ) dissolved in $25 \mathrm{~mL}$ of ethanol, $N$-methyl-1,2-benzenediamine $(0.56 \mathrm{~mL}, 5.0 \mathrm{mmol})$ in $15 \mathrm{~mL}$ of ethanol was added dropwise over the course of 30 minutes. The mixture was then stirred at $50{ }^{\circ} \mathrm{C}$ for two days. After cooling, $30 \mathrm{~mL}$ of $\mathrm{H}_{2} \mathrm{O}$ was added and the mixture was placed overnight in a freezer. The resulting brown precipitate was filtered and dried under vacuum to give the product $(0.79 \mathrm{~g}, 66 \%)$. Anal. Calcd for $\mathrm{C}_{14} \mathrm{H}_{12} \mathrm{~N}_{2} \mathrm{O}_{2}(\mathrm{MW}=$ $\left.240.26 \mathrm{~g} \mathrm{~mol}^{-1}\right): \mathrm{C}, 69.99 ; \mathrm{H}, 5.03 ; \mathrm{N}, 11.66$. Found: $\mathrm{C}, 69.84 ; \mathrm{H}$, 5.15; N, 11.70. ${ }^{1} \mathrm{H}$ NMR $(\delta, \mathrm{DMSO}): 3.81\left(\mathrm{~s}, 3 \mathrm{H}, \mathrm{NCH}_{3}\right), 6.83(\mathrm{~m}, 2 \mathrm{H})$, $7.02(\mathrm{~d}, 1 \mathrm{H}), 7.27(\mathrm{~m}, 2 \mathrm{H}), 7.63(\mathrm{~m}, 2 \mathrm{H}), 9.10(\mathrm{br} \mathrm{s}, 1 \mathrm{H},-\mathrm{OH})$, 10.43 (br s, $1 \mathrm{H},-\mathrm{OH}) .{ }^{13} \mathrm{C}\left\{{ }^{1} \mathrm{H}\right\}$ NMR (ס, DMSO): 31.6, 110.4, 116.0, $116.1117 .2,118.5,118.6,121.9,122.4,135.8,141.5,149.1,149.6$, 151.9 .

$\left[\mathrm{Fe}\left({ }^{\mathrm{Ph} 2} \mathrm{Tp}\right)\left(H L^{A}\right)\right](1 A)$ 2-(1-methyl-1H-benzimidazol-2$\mathrm{yl})$ hydroquinone $\left(\mathrm{H}_{2} \mathrm{~L}^{\mathrm{A}}\right)(120 \mathrm{mg}, 0.50 \mathrm{mmol})$ was deprotonated by reaction with one equivalent of NaOMe in $10 \mathrm{~mL}$ of $\mathrm{MeCN}$. To this solution was added $\mathrm{FeCl}_{2}(64.2 \mathrm{mg}, 0.50 \mathrm{mmol})$ and $\mathrm{K}\left({ }^{\mathrm{Ph} 2} \mathrm{Tp}\right)(350 \mathrm{mg}$, $0.49 \mathrm{mmol}$ ). The mixture was stirred for overnight and the solvent removed under vacuum to give a yellow-brown solid. The crude product was dissolved in $\mathrm{CH}_{2} \mathrm{Cl}_{2}$ and filtered; the resulting solution

Dalton Transactions, Vol. 41, No. 39 (October 2012): pg. 12244-12253. DOI. This article is @ Royal Society of Chemistry and permission has been granted for this version to appear in e-Publications@Marquette. Royal Society of Chemistry does not grant permission for this article to be further copied/distributed or hosted elsewhere without the express permission from Royal Society of Chemistry. 
yielded yellow crystals suitable for crystallographic analysis after standing for several days $(0.37 \mathrm{~g}, 77 \%)$. Anal. Calcd for $\mathrm{C}_{59} \mathrm{H}_{45} \mathrm{BFeN}_{8} \mathrm{O}_{2}$ $\left(\mathrm{MW}=964.70 \mathrm{~g} \mathrm{~mol}^{-1}\right): \mathrm{C}, 73.56 ; \mathrm{H}, 4.70 ; \mathrm{N}, 11.62$. Found: $\mathrm{C}$, 73.18; $\mathrm{H}, 4.87 ; \mathrm{N}, 11.72$. UV-vis $\left[\lambda_{\max }, \mathrm{nm}\left(\varepsilon, \mathrm{M}^{-1} \mathrm{~cm}^{-1}\right)\right.$ in $\left.\mathrm{CH}_{2} \mathrm{Cl}_{2}\right]$ : 369 (10,100). FTIR ( $\mathrm{cm}^{-1}$, solution): $3592(\mathrm{OH}), 3047,2988,2901$, $2611(\mathrm{BH}), 1543,1484,1415,1332,1243,1171,1070,1007,963$, $914,818,760,692$.

$\left[\mathrm{Fe}\left({ }^{\mathrm{Ph} 2} \mathrm{Tp}\right)\left(H L^{B}\right)\right](1 \mathrm{~B})$ Under an inert atmosphere, $182 \mathrm{mg}$ (1.20 mmol) of $2^{\prime}, 5^{\prime}$-dihydroxyacetophenone $\left(\mathrm{H}_{2} \mathrm{~L}^{\mathrm{B}}\right)$ was deprotonated by mixing with one equivalent of $\mathrm{NaOMe}$ in THF for 30 minutes, after which the solvent was removed to yield the $\mathrm{Na}\left(\mathrm{HL}^{\mathrm{B}}\right)$ salt as a white solid. To this compound was added anhydrous $\mathrm{FeCl}_{2}$ (146 mg, 1.15 $\mathrm{mmol})$ and $\mathrm{K}\left({ }^{\mathrm{Ph} 2} \mathrm{Tp}\right)(815 \mathrm{mg}, 1.15 \mathrm{mmol})$ in $15 \mathrm{ml}$ of MeCN. After stirring the reaction mixture overnight, the resulting solid was collected by vacuum filtration, dried, and redissolved in $\mathrm{CH}_{2} \mathrm{Cl}_{2}$. Layering with pentane provided reddish brown crystals suitable for Xray diffraction $(0.26 \mathrm{~g}, 26 \%)$. Anal. Calcd for $\mathrm{C}_{53} \mathrm{H}_{41} \mathrm{BFeN}_{6} \mathrm{O}_{3}(\mathrm{MW}=$ $\left.876.59 \mathrm{~g} \mathrm{~mol}^{-1}\right): \mathrm{C}, 72.62 ; \mathrm{H}, 4.71 ; \mathrm{N}, 9.59$. Found: $\mathrm{C}, 72.49 ; \mathrm{H}$, 4.79; $\mathrm{N}, 9.73$. UV-vis $\left[\lambda_{\max }, \mathrm{nm}\left(\varepsilon, \mathrm{M}^{-1} \mathrm{Cm}^{-1}\right)\right.$ in $\left.\mathrm{CH}_{2} \mathrm{Cl}_{2}\right]: 394$ (5410), 485 (780), 527 (690). FTIR ( $\mathrm{cm}^{-1}$, solid): $3559(\mathrm{OH}), 3058,2608$ $(\mathrm{BH}), 1604$ (COacetyl), 1547, 1475, 1462, 1430, 1411, 1359, 1340, 1327, 1299, 1197, 1164, 1062, 1006, 965, 917, 810, 759, 693.

$\left[F e\left({ }^{P h 2} T p\right)\left(H L^{C}\right)\right](1 C)$ The method of preparation was similar to the one described for $\mathbf{1 B}$, except that $2^{\prime}$-hydroxyacetophenone $\left(\mathrm{H}_{2} \mathrm{~L}^{\mathrm{C}}\right)$ was substituted for $\mathrm{H}_{2} \mathrm{~L}^{\mathrm{B}}$. Orange crystals were obtained by layering a concentrated $\mathrm{CH}_{2} \mathrm{Cl}_{2}$ solution with $\mathrm{MeCN}$. Yield $=24 \%$. Anal. Calcd for $\mathrm{C}_{53} \mathrm{H}_{41} \mathrm{BFeN}_{6} \mathrm{O}_{2}\left(\mathrm{MW}=860.59 \mathrm{~g} \mathrm{~mol}^{-1}\right): \mathrm{C}, 73.97 ; \mathrm{H}, 4.80 ; \mathrm{N}, 9.77$. Found: $\mathrm{C}, 74.15 ; \mathrm{H}, 4.92 ; \mathrm{N}, 9.83$. UV-Vis $\left[\lambda_{\max }, \mathrm{nm}\left(\varepsilon, \mathrm{M}^{-1} \mathrm{~cm}^{-1}\right)\right.$ in $\mathrm{CH}_{2} \mathrm{Cl}_{2}$ ]: 368 (5950), 441 (540), 485 (570). FTIR $\left(\mathrm{cm}^{-1}\right.$, solid): 3060, $2618(\mathrm{BH}), 1613$ (COacetyl), 1529, 1479, 1463, 1432, 1414, 1361, 1346, 1331, 1225, 1167, 1063, 1010, 966, 912, 863, 804, 753, 692.

$\left[\mathrm{Fe}\left({ }^{\mathrm{Ph} 2} \mathrm{Tp}\right)\left(H L^{D}\right)\right]$ (1D) This compound was prepared via two methods. Method A: 2-methoxyhydroquinone $\left(\mathrm{H}_{2} \mathrm{~L}^{\mathrm{D}}, 151 \mathrm{mg}, 1.1\right.$ $\mathrm{mmol})$ and triethylamine $(1.1 \mathrm{mmol})$ were stirred in $\mathrm{MeCN}$, followed by addition of $\mathrm{K}\left({ }^{\mathrm{Ph} 2} \mathrm{Tp}\right)(710 \mathrm{mg}, 1.0 \mathrm{mmol})$ and $\mathrm{Fe}(\mathrm{OTf})_{2}(372 \mathrm{mg}, 1.05$ mmol) dissolved in $\mathrm{CH}_{2} \mathrm{Cl}_{2}$ and $\mathrm{MeCN}$, respectively. The mixture was stirred overnight, filtered, and the solvent removed under vacuum.

Dalton Transactions, Vol. 41, No. 39 (October 2012): pg. 12244-12253. DOI. This article is @ Royal Society of Chemistry and permission has been granted for this version to appear in e-Publications@Marquette. Royal Society of Chemistry does not grant permission for this article to be further copied/distributed or hosted elsewhere without the express permission from Royal Society of Chemistry. 
The resulting solid was washed multiple times with MeCN to remove triflate salts and other impurities, then dried again. The solid was dissolved in $\mathrm{CH}_{2} \mathrm{Cl}_{2}$ and layered with hexane to yield a yellow crystalline powder $(0.28 \mathrm{~g}, 33 \%)$. Anal. Calcd for $\mathrm{C}_{52} \mathrm{H}_{41} \mathrm{BFeN}_{6} \mathrm{O}_{3}(\mathrm{MW}$ $\left.=864.58 \mathrm{~g} \mathrm{~mol}^{-1}\right): \mathrm{C}, 72.24 ; \mathrm{H}, 4.78 ; \mathrm{N} 9.72$. Found: $\mathrm{C}, 69.69 ; \mathrm{H}$, $5.65 ; \mathrm{N} 10.63$ (the discrepancies indicate the presence of small amounts of impurities). UV-Vis $\left[\lambda_{\max }, \mathrm{nm}\left(\varepsilon, \mathrm{M}^{-1} \mathrm{Cm}^{-1}\right)\right.$ in $\left.\mathrm{CH}_{2} \mathrm{Cl}_{2}\right]: 383$ (1490). FTIR ( $\mathrm{cm}^{-1}$, solid): $3563(\mathrm{OH}), 3056,2931,2615(\mathrm{BH}), 1543$, 1495, 1477, 1461, 1410, 1357, 1305, 1260, 1226, 1164, 1060, 1008, 913, 818, 754, 690. Method B: Equimolar amounts of the four reagents - $\mathrm{Fe}(\mathrm{OTf})_{2}, \mathrm{~K}\left({ }^{\mathrm{Ph} 2} \mathrm{Tp}\right), \mathrm{H}_{2} \mathrm{~L}^{\mathrm{D}}$, and $\mathrm{NEt}_{3}$ - were mixed in $\mathrm{CH}_{2} \mathrm{Cl}_{2}$ and stirred overnight. The solution was filtered and the solvent removed under vacuum. The solid was taken up in $\mathrm{CH}_{2} \mathrm{Cl}_{2}$ and layered with pentane to yield yellow crystals suitable for X-ray diffraction.

$\left[\mathrm{Fe}\left({ }^{\mathrm{Ph} 2} \mathrm{Tp}\right)\left(H L^{F}\right)\left({ }^{P h 2} \mathrm{pz}\right)\right]$ (1F) 3,5-diphenylpyrazole (236 mg, 1.04 $\mathrm{mmol}), \mathrm{K}\left({ }^{\mathrm{Ph} 2} \mathrm{Tp}\right)(714 \mathrm{mg}, 1.01 \mathrm{mmol})$, and 2,6-dimethylhydroquinone $\left(\mathrm{H}_{2} \mathrm{~L}^{\mathrm{F}}, 164 \mathrm{mg}, 1.19 \mathrm{mmol}\right)$ were dissolved in a $3: 1$ mixture of DCE: MeCN. To this solution was added $\mathrm{FeCl}_{2}(129 \mathrm{mg}, 1.02 \mathrm{mmol})$ in $\mathrm{MeCN}$ and NaOMe $(0.23 \mathrm{~mL}$ of $4.37 \mathrm{M} \mathrm{MeOH}$ solution, $1.00 \mathrm{mmol})$. The reaction was stirred overnight. The solvent was evaporated under vacuum to give a pale orange solid. The crude solid was taken up into DCE and filtered, providing bright yellow solution. Yellow crystals were obtained by layering this DCE solution with pentane. Anal. Calcd for $\mathrm{C}_{68} \mathrm{H}_{55} \mathrm{BFeN}_{8} \mathrm{O}_{2}\left(\mathrm{MW}=1082.88 \mathrm{~g} \mathrm{~mol}^{-1}\right): \mathrm{C}, 75.42 ; \mathrm{H}, 5.12 ; \mathrm{N} 10.35$. Found: $C, 75.22 ; \mathrm{H}, 5.00 ; \mathrm{N}$ 10.21. UV-Vis $\left[\lambda_{\max }, \mathrm{nm}\left(\varepsilon, \mathrm{M}^{-1} \mathrm{~cm}^{-1}\right)\right.$ in $\mathrm{CH}_{2} \mathrm{Cl}_{2}$ ]: 374 (2530). FTIR ( $\mathrm{cm}^{-1}$, solid): $3355(\mathrm{OH}), 3060,3038$, 2912, $2631(\mathrm{BH}), 1598,1543,1477,1465,1430,1410,1339,1306$, $1212,1165,1062,1004,967,913,851,810,754,688$.

$\left[\mathrm{Fe}_{2}\left({ }^{\mathrm{Ph} 2} \mathrm{Tp}\right)_{2}\left(\mu-L^{E}\right)\right]$ (2E) 2,5-dimethoxyhydroquinone $\left(\mathrm{H}_{2} \mathrm{~L}^{\mathrm{E}}, 91 \mathrm{mg}\right.$, $0.53 \mathrm{mmol}$ ) was first deprotonated by treatment with two equivalents of $\mathrm{NaOMe}$ in THF. After removal of the solvent, the resulting white solid $\mathrm{Na}_{2}\left(\mathrm{~L}^{\mathrm{E}}\right)$ was mixed with $\mathrm{FeCl}_{2}(131 \mathrm{mg}, 1.03 \mathrm{mmol})$ and $\mathrm{K}\left({ }^{\mathrm{Ph}}{ }^{\mathrm{T}} \mathrm{Tp}\right)$ (715 mg, $1.01 \mathrm{mmol}$ ) in MeCN, and the solution was stirred overnight. After removal of the solvent under vacuum, the yellow solid was taken up $\mathrm{CH}_{2} \mathrm{Cl}_{2}$ and the solution filtered to remove unwanted salts. Vapor diffusion of $\mathrm{Et}_{2} \mathrm{O}$ into this $\mathrm{CH}_{2} \mathrm{Cl}_{2}$ solution provided yellow-orange needles suitable for X-ray crystallography $(0.11 \mathrm{~g}, 13 \%)$. Anal. Calcd for $\mathrm{C}_{98} \mathrm{H}_{76} \mathrm{~B}_{2} \mathrm{Fe}_{2} \mathrm{~N}_{12} \mathrm{O}_{4}\left(\mathrm{MW}=1619.07 \mathrm{~g} \mathrm{~mol}^{-1}\right): \mathrm{C}, 72.70 ; \mathrm{H}, 4.73 ; \mathrm{N}$ 
10.38. Found: $C, 72.45 ; H, 4.67 ; N, 10.36$. UV-Vis $\left[\lambda_{\max }, \mathrm{nm}(\varepsilon\right.$, $\mathrm{M}^{-1} \mathrm{~cm}^{-1}$ ) in $\left.\mathrm{CH}_{2} \mathrm{Cl}_{2}\right]: 317$ (9300), 370 (sh), 444 (sh). FTIR $\left(\mathrm{cm}^{-1}\right.$, solid): 3058, 2926, 2614 (BH), 1541, 1478, 1465, 1438, 1407, 1359, $1260,1221,1194,1167,1154,1061,1008,888,802,756,690$.

$\left[\mathrm{Fe}_{2}\left({ }^{\mathrm{Ph} 2} \mathrm{Tp}\right)_{2}\left(\mu-L^{\mathrm{F}}\right)(\mathrm{MeCN})\right][2 \mathrm{~F}(\mathrm{MeCN})]$ Anhydrous $\mathrm{FeCl}_{2}(130 \mathrm{mg}$, $1.02 \mathrm{mmol})$ and $\mathrm{K}\left({ }^{\mathrm{Ph} 2} \mathrm{Tp}\right)(715 \mathrm{mg}, 1.01 \mathrm{mmol})$ were combined with 0.5 equivalent of 2,6-dimethylhydroquinone $\left(\mathrm{H}_{2} \mathrm{~L}^{\mathrm{F}}, 70.0 \mathrm{mg}, 0.51\right.$ $\mathrm{mmol}$ ) in $10 \mathrm{~mL}$ of $\mathrm{MeCN}$. To this mixture was added $0.23 \mathrm{~mL}$ of 4.37 $M$ solution of NaOMe $(1.01 \mathrm{mmol})$. The reaction was stirred overnight, and the solvent removed under vacuum. The resulting solid was dissolved in DCE, filtered, and then layered with MeCN to provide reddish-brown needles $(0.21 \mathrm{~g}, 26 \%)$ suitable for crystallographic analysis. The X-ray structure revealed two uncoordinated DCE molecules in the asymmetric unit, and elemental analysis suggest that a small amount of solvent ( 0.8 equiv.) remains even after drying. Anal. Calcd for $\mathrm{C}_{100} \mathrm{H}_{79} \mathrm{~B}_{2} \mathrm{Fe}_{2} \mathrm{~N}_{13} \mathrm{O}_{2} \bullet 0.8 \mathrm{DCE}\left(\mathrm{MW}=1707.27 \mathrm{~g} \mathrm{~mol}^{-1}\right): \mathrm{C}$, $71.48 ; \mathrm{H}, 4.85 ; \mathrm{N} 10.67$. Found: $\mathrm{C}, 71.47 ; \mathrm{H}, 4.77 ; \mathrm{N}, 10.37$. UV-Vis $\left[\lambda_{\max }, \mathrm{nm}\left(\varepsilon, \mathrm{M}^{-1} \mathrm{~cm}^{-1}\right)\right.$ in $\left.\mathrm{CH}_{2} \mathrm{Cl}_{2}\right]: 288(11,500), 377$ (3600). FTIR (cm-1, solid): 3052, 2925, $2608(\mathrm{BH}), 1542,1465,1477,1431,1412$, 1358, 1242, 1162, 1065, 1029, 1009, 969, 916, 847, 810.

\section{Crystallographic Studies}

Each complex was characterized with X-ray crystallography; details concerning the data collection and analysis are summarized in Table 3. The X-ray diffraction data were collected at $100 \mathrm{~K}$ with an Oxford Diffraction SuperNova kappa-diffractometer equipped with dual microfocus $\mathrm{Cu} / \mathrm{Mo} \mathrm{X}$-ray sources, $\mathrm{X}$-ray mirror optics, Atlas CCD detector and a low-temperature Cryojet device. The data were processed with CrysAlisPro program package (Oxford Diffraction Ltd., 2010) typically using a numerical Gaussian absorption correction (based on the real shape of the crystal) followed by an empirical multiscan correction using SCALE3 ABSPACK routine. The structures were solved using the SHELXS program and refined with the SHELXL program $^{31}$ within the Olex 2 crystallographic package. ${ }^{32}$ All computations were performed on an Intel PC computer with Windows 7 OS. Some structures contain disorder that was detected in difference Fourier syntheses of electron density and accounted for using capabilities of the SHELX package. In most cases, hydrogen atoms

Dalton Transactions, Vol. 41, No. 39 (October 2012): pg. 12244-12253. DOI. This article is @ Royal Society of Chemistry and permission has been granted for this version to appear in e-Publications@Marquette. Royal Society of Chemistry does not grant permission for this article to be further copied/distributed or hosted elsewhere without the express permission from Royal Society of Chemistry. 
were localized in difference syntheses of electron density but were refined using appropriate geometric restrictions on the corresponding bond lengths and bond angles within a riding/rotating model (torsion angles of methyl hydrogens were optimized to better fit the residual electron density).

\section{Supplementary Material}

\section{Electronic Supporting Information(ESI) for:}

\section{Structural, Spectroscopic, and Electrochemical Properties of Nonheme Fe(II)-Hydroquinonate Complexes: Synthetic Models of Hydroquinone Dioxygenases}

Amanda E. Baum, Heaweon Park, Denan Wang, Sergey V. Lindeman, and Adam T. Fiedler*

Department of Chemistry, Marquette University, Milwaukee, WI 53201-1881

Email: adam.fiedler@marquette.edu

\section{Contents}

Figures S1-S3 
NOT THE PUBLISHED VERSION; this is the author's final, peer-reviewed manuscript. The published version may be accessed by following the link in the citation at the bottom of the page.

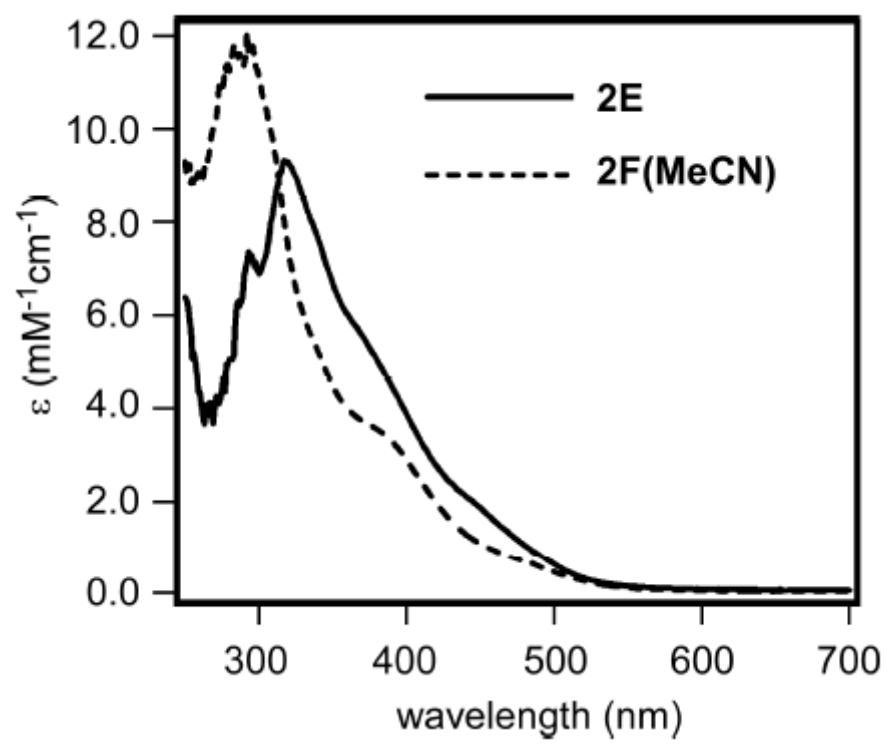

Figure S1. Electronic absorption spectra of $\mathbf{2 E}$ and $\mathbf{2} \mathbf{F}(\mathbf{M e C N})$ in $\mathrm{CH} 2 \mathrm{Cl} 2$ at room temperature.

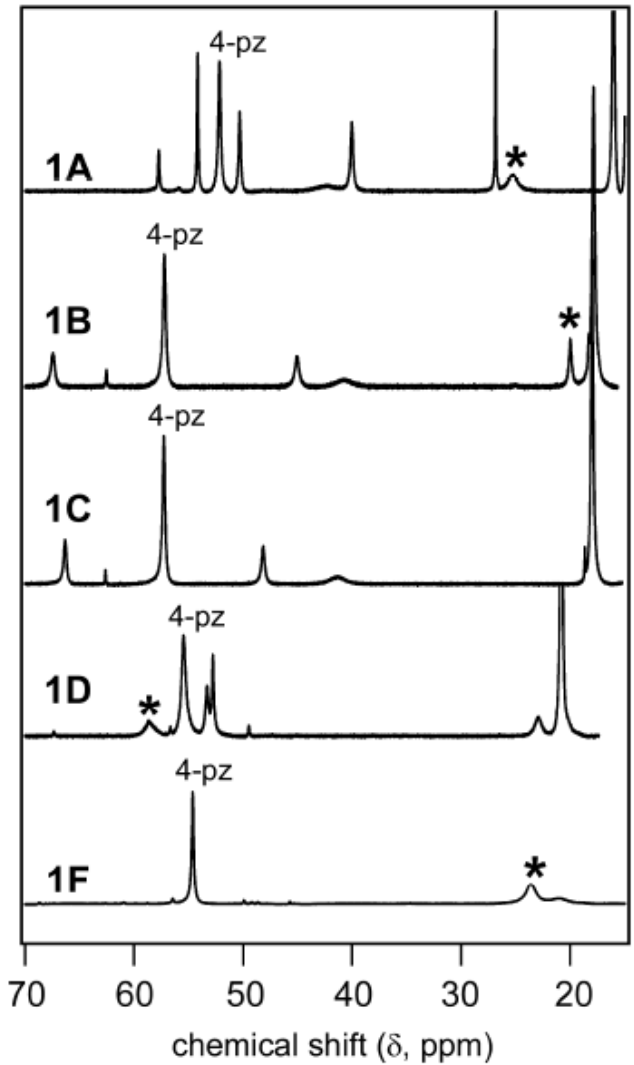

Dalton Transactions, Vol. 41, No. 39 (October 2012): pg. 12244-12253. DOI. This article is @ Royal Society of Chemistry and permission has been granted for this version to appear in e-Publications@Marquette. Royal Society of Chemistry does not grant permission for this article to be further copied/distributed or hosted elsewhere without the express permission from Royal Society of Chemistry. 
NOT THE PUBLISHED VERSION; this is the author's final, peer-reviewed manuscript. The published version may be accessed by following the link in the citation at the bottom of the page.

Figure S2. ${ }^{1} \mathrm{H}$ NMR spectra of $\mathbf{1 A - 1 D}$, and $\mathbf{1 F}$ in $\mathrm{CD}_{2} \mathrm{Cl}_{2}$ at ambient temperature. Peaks marked with an asterisk $(*)$ disappeared upon addition of a small amount of $\mathrm{MeOH}-\mathrm{d}_{4}$ and are therefore assigned to the exchangeable proton of the distal $-\mathrm{OH}$ moiety. Resonances arising from protons at the 4-positions of the ${ }^{\mathrm{Ph}} 2 \mathrm{Tp}$ pyrazole rings (4-pz) were identified on the basis of peak integrations.

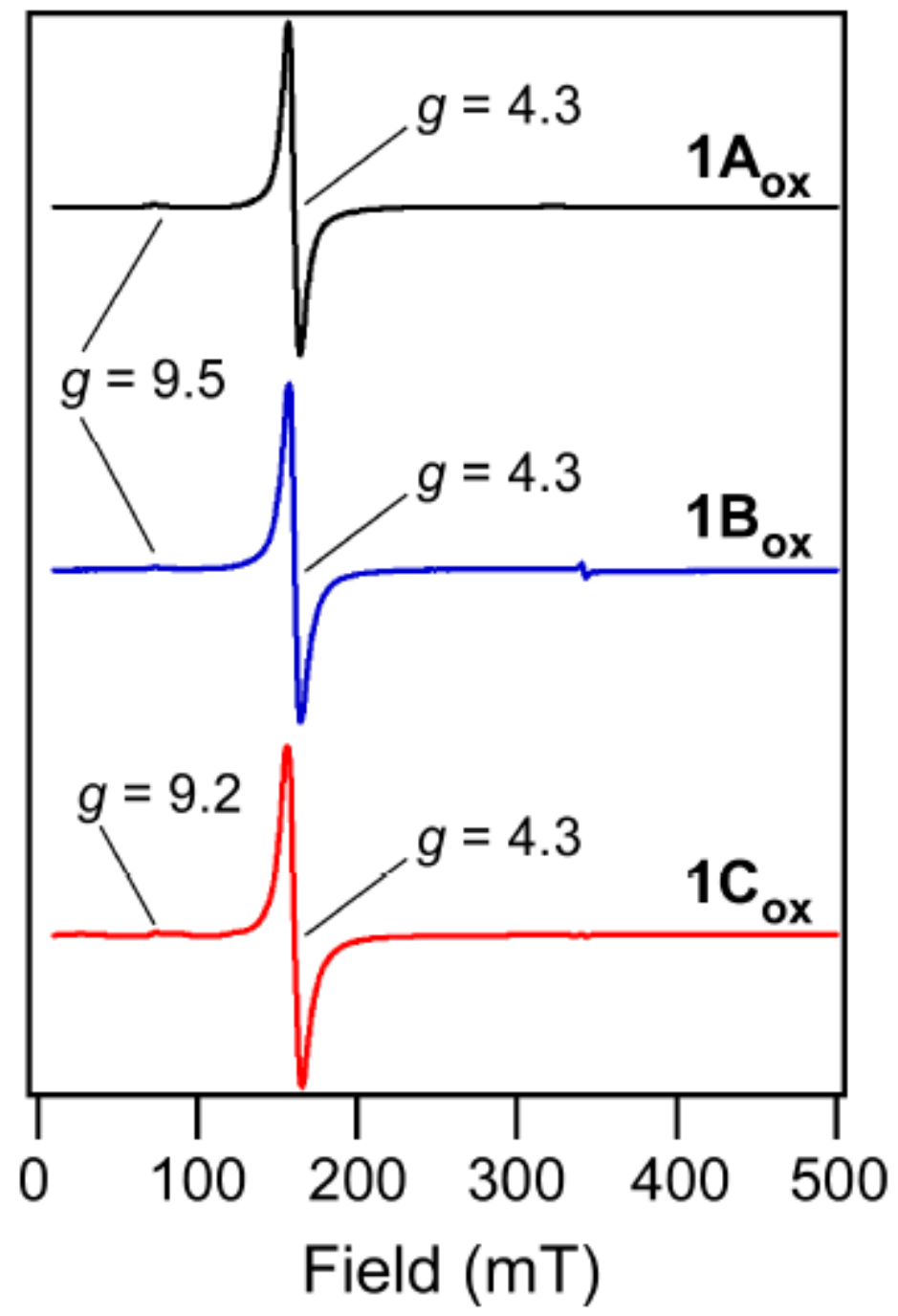

Figure S3. $X$-band EPR spectra of $1 A_{o x}-1 C_{o x}$ in frozen $\mathrm{CH} 2 \mathrm{Cl} 2$ solutions. The $1 \mathrm{X}_{\mathrm{ox}}$ species were obtained by treating the $\mathrm{Fe}(\mathrm{II})$ precursors with one equivalent of acetylferrocenuium $\left(1 \mathrm{~A}_{\text {ox }}\right)$ or $\left[\mathrm{N}\left(\mathrm{C}_{6} \mathrm{H}_{4} \mathrm{Br}-4\right)_{3}\right]+\left(1 \mathrm{~B}_{\text {ox }}\right.$ and $\left.1 \mathrm{C}_{\mathrm{ox}}\right)$. The spectra were collected under the following conditions: frequency $=9.63 \mathrm{GHz}$; power $=2.0 \mathrm{~mW}$; modulation $=12 \mathrm{G}$; temperature $=10 \mathrm{~K}$. and permission has been granted for this version to appear in e-Publications@Marquette. Royal Society of Chemistry does not grant permission for this article to be further copied/distributed or hosted elsewhere without the express permission from Royal Society of Chemistry. 
NOT THE PUBLISHED VERSION; this is the author's final, peer-reviewed manuscript. The published version may be accessed by following the link in the citation at the bottom of the page.

\section{Computational Details.}

Density functional theory (DFT) calculations of complex 1B were performed using the ORCA 2.0 software package developed by Dr. F. Neese. ${ }^{1}$ Atomic coordinates were obtained from the corresponding Xray structure, although the 5 -Ph groups of the ${ }^{\mathrm{Ph} 2} \mathrm{Tp}$ ligand were replaced by $-\mathrm{CH} 3$ groups in the computational model. The DFT calculations employed the Becke-Perdew (BP86) functional ${ }^{2}$ and Ahlrichs' valence triple- $\zeta$ basis set (TZV) for all atoms, in conjunction with the TZV/J auxiliary basis set. ${ }^{3}$ Extra polarization functions were used on non-hydrogen atoms. Time-dependent DFT (TD-DFT) calculations ${ }^{4}$ provided absorption energies and intensities within the Tamm-Dancoff approximation. ${ }^{5}$ Forty excited states were calculated.

1. Neese, F.; ORCA - An ab initio, Density Functional and Semi-empirical Program Package, version 2.8; University of Bonn: Bonn, Germany, 2010.

2. (a) Becke, A. D. J. Chem. Phys. 1986, 84, 4524-4529. (b) Perdew, J. P. Phys. Rev. B 1986, 33, 8822-8824.

3. (a) Schafer, A.; Horn, H.; Ahlrichs, R. J. Chem. Phys. 1992, 97, 25712577. (b) Schafer, A.; Huber, C.; Ahlrichs, R. J. Chem. Phys. 1994, $100,5829-5835$.

4. (a) Stratmann, R. E.; Scuseria, G. E.; Frisch, M. J. J. Chem. Phys. 1998, 109, 8218-8224. (b) Casida, M. E.; Jamorski, C.; Casida, K. C.;

Salahub, D. R. J. Chem. Phys. 1998, 108, 4439-4449. (c)

Bauernschmitt, R.; Ahlrichs, R. Chem. Phys. Lett. 1996, 256, 454464.

5. (a) Hirata, S.; Head-Gordon, M. Chem. Phys. Lett. 1999, 314, 291-299. (b) Hirata, S.; Head-Gordon, M. Chem. Phys. Lett. 1999, 302, 375382.

\section{Acknowledgments}

We thank Dr. Brian Bennett for allowing us to perform EPR experiments at the National Biomedical EPR Center (supported by NIH P41 grant EB001980). A.T.F. also thanks Marquette University and the National Science Foundation (CAREER CHE-1056845) for generous financial support.

Dalton Transactions, Vol. 41, No. 39 (October 2012): pg. 12244-12253. DOI. This article is @ Royal Society of Chemistry and permission has been granted for this version to appear in e-Publications@Marquette. Royal Society of Chemistry does not grant permission for this article to be further copied/distributed or hosted elsewhere without the express permission from Royal Society of Chemistry. 
NOT THE PUBLISHED VERSION; this is the author's final, peer-reviewed manuscript. The published version may be accessed by following the link in the citation at the bottom of the page.

\section{Notes and References}

1. (a) Gibson DT, Parales RE. Curr Opin Biotechnol. 2000;11:236-243.

(b) Parales R, Resnick SM. In: Biodegradation and Bioremediation. Singh A, Ward OP, editors. Springer; Heidelberg: 2004. pp. 175-196. (c) Furukawa K. Curr Opin Biotechnol. 2000;11:244-249.

2. (a) Vaillancourt FH, Bolin JT, Eltis LD. Crit Rev Biochem Mol Biol. 2006;41:241-267.

(b) Costas M, Mehn MP, Jensen MP, Que L., Jr Chem Rev. 2004;104:939-986.

3. Koehntop KD, Emerson JP, Que L., Jr J Biol Inorg Chem. 2005;10:87-93.

4. (a) Straganz GD, Nidetzky B. Chembiochem. 2006;7:1536-1548.

(b) Diebold AR, Neidig ML, Moran GR, Straganz GD, Solomon EI. Biochemistry. 2010;49:6945-6952.

5. (a) Lipscomb JD. Curr Opin Struct Biol. 2008;18:644-649.

(b) Bugg TDH, Ramaswamy S. Curr Opin Chem Biol. 2008;12:134140.

(c) Bruijnincx PCA, van Koten G, Gebbink RJMK. Chem Soc Rev. 2008;37:2716-2744.

(d) Siegbahn PEM, Haeffner F. J Am Chem Soc. 2004;126:8919-8932.

(e) Solomon EI, Brunold TC, Davis MI, Kemsley JN, Lee SK, Lehnert N, Neese F, Skulan AJ, Yang YS, Zhou J. Chem Rev. 2000;100:235-349.

6. Lipscomb JD, Orville AM. In: Met Ions Biol Syst. Sigel H, Sigel A, editors. Vol. 28. Marcel Dekker; New York: 1992. pp. 243-298.

7. (a) Li XW, Guo M, Fan J, Tang WY, Wang DQ, Ge HH, Rong H, Teng MK, Niu LW, Liu Q, Hao Q. Protein Sci. 2006;15:761-773.

(b) Zhang Y, Colabroy KL, Begley TP, Ealick SE. Biochemistry. 2005;44:7632-7643.

(c) Lendenmann U, Spain JC. J Bacteriol. 1996;178:6227-6232.

8. (a) Matera I, Ferraroni M, Burger S, Scozzafava A, Stolz A, Briganti F. J Mol Biol. 2008;380:856-868.

(b) Hintner JP, Lechner C, Riegert U, Kuhm AE, Storm T, Reemtsma T, Stolz A. J Bacteriol. 2001;183:6936-6942.

(c) Hintner JP, Remtsma T, Stolz A. J Biol Chem. 2004;279:3725037260.

Dalton Transactions, Vol. 41, No. 39 (October 2012): pg. 12244-12253. DOI. This article is @ Royal Society of Chemistry and permission has been granted for this version to appear in e-Publications@Marquette. Royal Society of Chemistry does not grant permission for this article to be further copied/distributed or hosted elsewhere without the express permission from Royal Society of Chemistry. 
9. (a) Harpel MR, Lipscomb JD. J Biol Chem. 1990;265:22187-22196.

(b) Chen J, Li W, Wang MZ, Zhu GY, Liu DQ, Sun F, Hao N, Li XM, Rao ZH, Zhang XC. Protein Sci. 2008;17:1362-1373.

10. (a) Veldhuizen EJA, Vaillancourt FH, Whiting CJ, Hsiao MMY, Gingras G, Xiao YF, Tanguay RM, Boukouvalas J, Eltis LD. Biochem J. 2005;386:305-314.

(b) Titus GP, Mueller HA, Burgner J, Córdoba SRd, Penalva MA, Timm DE. Nat Struct Biol. 2000;7:542-546.

11. Borowski T, Georgiev V, Siegbahn PEM. J Am Chem Soc. 2005;127:17303-17314.

12. (a) Machonkin TE, Doerner AE. Biochemistry. 2011;50:8899-8913. (b) Machonkin TE, Holland PL, Smith KN, Liberman JS, Dinescu A, Cundari TR, Rocks SS. J Biol Inorg Chem. 2010;15:291-301.

(c) Xu L, Resing K, Lawson SL, Babbitt PC, Copley SD. Biochemistry. 1999;38:7659-7669.

(d) Ohtsubo Y, Miyauchi K, Kanda K, Hatta T, Kiyohara H, Senda T, Nagata Y, Mitsui Y, Takagi M. FEBS Lett. 1999;459:395-398.

13. (a) Nagata $Y$, Endo $R$, Ito $M$, Ohtsubo $Y$, Tsuda M. Appl Microbiol Biotechnol. 2007;76:741-752.

(b) Miyauchi K, Adachi Y, Nagata Y, Takagi M. J Bacteriol. 1999;181:6712-6719.

14. Yin Y, Zhou NY. Curr Microbiol. 2010;61:471-476.

15. Christian GJ, Ye SF, Neese F. Chem Sci. 2012;3:1600-1611.

16. (a) Kovaleva EG, Lipscomb JD. Science. 2007;316:453-457. (b) Bugg TDH, Lin G. Chem Commun. 2001;11:941-953.

17. Becker JM, Barker J, Clarkson GJ, van Gorkum R, Johal GK, Walton RI, Scott P. Dalton Trans. 2010;39:2309-2326.

18. (a) Heistand RH, II, Roe AL, Que L., Jr Inorg Chem. 1982;21:676-681. (b) Maroney MJ, Day RO, Psyris T, Fleury LM, Whitehead JP. Inorg Chem. 1989;28:173-175.

19. Rheingold AL, Miller J. Private communication to Cambridge Structural Database. 2003.

20. Rocks SS, Brennessel WW, Machonkin TE, Holland PL. Inorg Chem. 2010;49:10914-10929. and permission has been granted for this version to appear in e-Publications@Marquette. Royal Society of Chemistry does not grant permission for this article to be further copied/distributed or hosted elsewhere without the express permission from Royal Society of Chemistry. 
NOT THE PUBLISHED VERSION; this is the author's final, peer-reviewed manuscript. The published version may be accessed by following the link in the citation at the bottom of the page.

21. (a) Paria S, Que L, Paine TK. Angew Chem Intl Ed. 2011;50:1112911132.

(b) Mukherjee A, Cranswick MA, Chakrabarti M, Paine TK, Fujisawa K, Munck E, Que L. Inorg Chem. 2010;49:3618-3628.

(c) Bruijnincx PCA, Lutz M, Spek AL, Hagen WR, Weckhuysen BM, vanKoten G, Gebbink RJMK. J Am Chem Soc. 2007;129:2275-2286.

(d) Mehn MP, Fujisawa K, Hegg EL, Que L., Jr J Am Chem Soc. 2003; 125:7828-7842.

(e) Ogihara T, Hikichi S, Akita M, Morooka Y. Inorg Chem. $1998 ; 37: 2614-2615$

22. (a) Park H, Baus JS, Lindeman SV, Fiedler AT. Inorg Chem. 2011;50:11978-11989.

(b) Siewert I, Limberg C. Angew Chem Intl Ed. 2008;47:7953-7956.

23. (a) Paria $S$, Halder $P$, Chakraborty $B$, Paine TK. Indian J Chem, Sect A. 2011;50:420-426.

(b) Fujisawa K, Tada N, Nishida Y, Miyashita Y, Okamoto K. Inorg Chem Commun. 2008;11:381-384.

24. Addison AW, Rao TN, Reedijk J, Vanrijn J, Verschoor GC. J Chem Soc, Dalton Trans. 1984:1349-1356.

25. Warren JJ, Tronic TA, Mayer JM. Chem Rev. 2010;110:6961-7001.

26. (a) Ito $M$, Amagai $H$, Fukui $H$, Kitajima N, MoroOka Y. Bull Chem Soc Jpn. 1996;69:1937-1945.

(b) Pyrz JW, Roe AL, Stern LJ, Que L., Jr J Am Chem Soc. $1985 ; 107: 614-620$.

27. Davis MI, Orville AM, Neese F, Zaleski JM, Lipscomb JD, Solomon EI. J Am Chem Soc. 2002;124:602-614.

28. (a) Sato N, Uragami $Y$, Nishizaki T, Takahashi $Y$, Sazaki G, Sugimoto $K$, Nonaka T, Masai E, Fukuda M, Senda T. J Mol Biol. 2002;321:621-636. (b) Vaillancourt FH, Barbosa CJ, Spiro TG, Bolin JT, Blades MW, Turner RFB, Eltis LD. J Am Chem Soc. 2002;124:2485-2496.

29. Kitajima N, Fujisawa L, Fujimoto C, Moro-oka Y, Hashimoto S, Kitagawa T, Toriumi K, Tatsumi K, Nakamura A. J Am Chem Soc. 1992;114:12771291.

30. Hanss D, Walther ME, Wenger OS. Chem Commun. 2010;46:7034-7036.

31. Sheldrick GM. Acta Crystallogr Sect A. 2008;64:112-122.

Dalton Transactions, Vol. 41, No. 39 (October 2012): pg. 12244-12253. DOI. This article is @ Royal Society of Chemistry and permission has been granted for this version to appear in e-Publications@Marquette. Royal Society of Chemistry does not grant permission for this article to be further copied/distributed or hosted elsewhere without the express permission from Royal Society of Chemistry. 
NOT THE PUBLISHED VERSION; this is the author's final, peer-reviewed manuscript. The published version may be accessed by following the link in the citation at the bottom of the page.

32. Dolomanov OV, Bourhis LJ, Gildea RJ, Howard JAK, Puschmann H. J Appl Crystallogr. 2009;42:339-341.

\title{
About the Authors
}

\author{
Adam T. Fiedler : Department of Chemistry, Marquette University \\ Milwaukee, WI, USA. \\ E-mail: adam.fiedler@marquette.edu
}

Dalton Transactions, Vol. 41, No. 39 (October 2012): pg. 12244-12253. DOI. This article is (C) Royal Society of Chemistry and permission has been granted for this version to appear in e-Publications@Marquette. Royal Society of Chemistry does not grant permission for this article to be further copied/distributed or hosted elsewhere without the express permission from Royal Society of Chemistry. 